Biogeosciences, 10, 4117-4135, 2013

www.biogeosciences.net/10/4117/2013/

doi:10.5194/bg-10-4117-2013

(C) Author(s) 2013. CC Attribution 3.0 License.

\title{
Nitrogen transfers off Walvis Bay: a 3-D coupled physical/biogeochemical modeling approach in the Namibian upwelling system
}

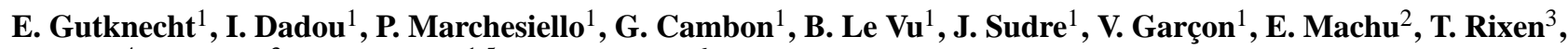 \\ A. Kock ${ }^{4}$, A. Flohr ${ }^{3}$, A. Paulmier ${ }^{1,5}$, and G. Lavik ${ }^{6}$ \\ ${ }^{1}$ Laboratoire d'Etudes en Géophysique et Océanographie Spatiales (UMR5566, CNRS/CNES/UPS/IRD), Toulouse, France \\ ${ }^{2}$ Laboratoire de Physique des Océans (UMR6523, CNRS/Ifremer/IRD/UBO), Plouzané, France \\ ${ }^{3}$ Leibniz Center for Tropical Marine Ecology, Bremen, Germany \\ ${ }^{4}$ Forschungsbereich Marine Biogeochemie, Helmholtz-Zentrum für Ozeanforschung, Kiel, Germany \\ ${ }^{5}$ Instituto del Mar del Perú, Esquina Gamarra y General Valle S/N chucuito Callao (Lima), Peru \\ ${ }^{6}$ Max Plank Institut for Marine Microbiology, Bremen, Germany \\ Correspondence to: E. Gutknecht (elodie.gutknecht@mercator-ocean.fr) and I. Dadou (isabelle.dadou@legos.obs-mip.fr)
}

Received: 25 February 2011 - Published in Biogeosciences Discuss.: 4 April 2011

Revised: 22 April 2013 - Accepted: 30 April 2013 - Published: 21 June 2013

\begin{abstract}
Eastern boundary upwelling systems (EBUS) are regions of high primary production often associated with oxygen minimum zones (OMZs). They represent key regions for the oceanic nitrogen $(\mathrm{N})$ cycle. By exporting organic matter $(\mathrm{OM})$ and nutrients produced in the coastal region to the open ocean, EBUS can play an important role in sustaining primary production in subtropical gyres. However, losses of fixed inorganic $\mathrm{N}$ through denitrification and anammox processes take place in oxygen depleted environments such as EBUS, and can potentially mitigate the role of these regions as a source of $\mathrm{N}$ to the open ocean. EBUS can also represent a considerable source of nitrous oxide $\left(\mathrm{N}_{2} \mathrm{O}\right)$ to the atmosphere, affecting the atmospheric budget of $\mathrm{N}_{2} \mathrm{O}$.

In this paper a 3-D coupled physical/biogeochemical model (ROMS/BioEBUS) is used to investigate the $\mathrm{N}$ budget in the Namibian upwelling system. The main processes linked to EBUS and associated OMZs are taken into account. The study focuses on the northern part of the Benguela upwelling system (BUS), especially the Walvis Bay area (between $22^{\circ} \mathrm{S}$ and $24^{\circ} \mathrm{S}$ ) where the $\mathrm{OMZ}$ is well developed. Fluxes of $\mathrm{N}$ off the Walvis Bay area are estimated in order to understand and quantify (1) the total $\mathrm{N}$ offshore export from the upwelling area, representing a possible $\mathrm{N}$ source that sustains primary production in the South Atlantic subtropical gyre; (2) export production and subsequent losses of
\end{abstract}

fixed $\mathrm{N}$ via denitrification and anammox under suboxic conditions $\left(\mathrm{O}_{2}<25 \mathrm{mmol} \mathrm{O}_{2} \mathrm{~m}^{-3}\right)$; and (3) the $\mathrm{N}_{2} \mathrm{O}$ emission to the atmosphere in the upwelling area.

In the mixed layer, the total $\mathrm{N}$ offshore export is estimated as $8.5 \pm 3.9 \times 10^{10} \mathrm{~mol} \mathrm{Nyr}^{-1}$ at $10^{\circ} \mathrm{E}$ off the Walvis Bay area, with a mesoscale contribution of $20 \%$. Extrapolated to the whole BUS, the coastal $\mathrm{N}$ source for the subtropical gyre corresponds to $0.1 \pm 0.04 \mathrm{~mol} \mathrm{~N} \mathrm{~m}^{-2} \mathrm{yr}^{-1}$. This $\mathrm{N}$ flux represents a major source of $\mathrm{N}$ for the gyre compared with other $\mathrm{N}$ sources, and contributes $28 \%$ of the new primary production estimated for the South Atlantic subtropical gyre.

Export production $\left(16.9 \pm 1.3 \times 10^{10} \mathrm{~mol} \mathrm{~N} \mathrm{yr}^{-1}\right)$ helps to maintain an OMZ off Namibia in which coupled nitrification, denitrification and anammox processes lead to losses of fixed $\mathrm{N}$ and $\mathrm{N}_{2} \mathrm{O}$ production. However, neither $\mathrm{N}$ losses $\left(0.04 \pm 0.025 \times 10^{10} \mathrm{~mol} \mathrm{Nyr}^{-1}\right)$ nor $\mathrm{N}_{2} \mathrm{O}$ emissions $\left(0.03 \pm 0.002 \times 10^{10} \mathrm{~mol} \mathrm{~N} \mathrm{yr}^{-1}\right)$ significantly impact the main $\mathrm{N}$ exports of the Walvis Bay area.

The studied area does not significantly contribute to $\mathrm{N}_{2} \mathrm{O}$ emissions ( 0.5 to $2.7 \%$ ) compared to the global coastal upwelling emissions. Locally produced $\mathrm{N}_{2} \mathrm{O}$ is mostly advected southward by the poleward undercurrent. 


\section{Introduction}

Although eastern boundary upwelling systems (EBUS) represent less than $1 \%$ of the global areas of the oceans, they contribute about $11 \%$ of the global oceanic new primary production (Chavez and Toggweiler, 1995; Carr, 2002; Carr and Kearns, 2003; Monteiro, 2010) and $20 \%$ of the global catches (Fréon et al., 2009). Thus, EBUS are important for the socio-economic activity of surrounding countries and for the global economy. This high primary production inducing high aerobic remineralization associated with large-scale circulation also allows the development and maintenance of oxygen minimum zones (OMZs; Paulmier and Ruiz-Pino, 2009). Recent studies have revealed an expansion and an intensification of these OMZs over the last fifty years (Stramma et al., 2008; Keeling et al., 2010) due to stronger ocean stratification and weaker ocean ventilation (Stramma et al., 2008, 2010). This phenomenon is more critical in the coastal areas than in the open ocean (Gilbert et al., 2010), especially for the EBUS. In particular, the tropical Atlantic Ocean presents the most intense decline in oxygen concentrations of the global ocean (Stramma et al., 2008, 2010). Due to the postulated reduced availability of oxygen in the ocean as a result of global change, the OMZs have received increasing interest in the international scientific community. However, global models currently fail to represent OMZs due to coarse spatial resolution and poor representation of biogeochemical processes. The development of regional models able to represent EBUS and associated OMZs is crucial as these regions play a key role for the global oceanic nitrogen $(\mathrm{N})$ cycle. Currently, the $\mathrm{N}$ budget is not balanced (Gruber and Galloway, 2008). For instance, several unknowns persist for the major $\mathrm{N}$ loss fluxes such as denitrification or anammox processes. These oxygen-dependent processes are particularly active in EBUS and associated OMZs, and lead to losses of fixed $\mathrm{N}$ from the ocean and nitrous oxide $\left(\mathrm{N}_{2} \mathrm{O}\right)$ emissions to the atmosphere (Codispoti et al., 2001; Cornejo et al., 2006; Farias et al., 2007; Paulmier et al., 2008). The oxygen decline presently observed in EBUS might therefore lead to an increase in oceanic losses of fixed $\mathrm{N}$ and emissions of $\mathrm{N}_{2} \mathrm{O}$ (Codispoti et al., 2001; Codispoti, 2010; Naqvi et al., 2010).

$\mathrm{N}_{2} \mathrm{O}$ is a greenhouse gas with a global warming potential $\sim 300$ times more efficient than carbon dioxide $\mathrm{CO}_{2}$ (Jain et al., 2000; Ramaswamy et al., 2001). Its present increase in the atmosphere plays a determining role in the budgets of stratospheric ozone and tropospheric heat (Denman et al., 2007). The global ocean is a major source of $\mathrm{N}_{2} \mathrm{O}$, contributing about $30-40 \%$ of the atmospheric $\mathrm{N}_{2} \mathrm{O}$ budget (Bange, 2006; Denman et al., 2007). Coastal upwellings could contribute up to $50 \%$ of the oceanic source (Nevison et al., 2003) due to the two main microbial processes affecting the $\mathrm{N}_{2} \mathrm{O}$ cycle: denitrification, which generates a loss of fixed nitrogen with $\mathrm{N}_{2} \mathrm{O}$ as a gaseous intermediate to $\mathrm{N}_{2}$; and nitrification, which is the oxidation of ammonium to nitrate, with $\mathrm{N}_{2} \mathrm{O}$ as a by-product (i.e., Bange, 2008). In this study, we are inter- ested in quantifying losses of fixed $\mathrm{N}$ through denitrification and anammox processes and estimating the $\mathrm{N}_{2} \mathrm{O}$ emissions to the atmosphere.

Uncertainties also remain in the ability of nutrient sources to sustain primary production in the subtropical gyres of the ocean. Several processes could be at work: (1) $\mathrm{N}_{2}$ biological fixation; (2) atmospheric deposition of reactive nitrogen; (3) Ekman transport of nutrients and organic matter (OM) from the enriched borders of the subtropical gyres; and (4) transport of nutrients and OM by mesoscale activity. By exporting $\mathrm{OM}$ and nutrients produced in the coastal upwelling areas to the open ocean, EBUS could represent a significant source of nitrogen, especially on the eastern border of the subtropical gyres, but also in remote locations. For example, OM produced in the Canary upwelling system could irrigate the North Atlantic Ocean (Pelegrí et al., 2006). However, losses of fixed $\mathrm{N}$ described above, taking place in oxygen-depleted environments such as EBUS, could mitigate the $\mathrm{N}$ source effect to the subtropical gyre.

One system in which we expect significant shelf/offshore interactions is the Benguela upwelling system (BUS) in the South Atlantic Ocean, off the South African and Namibian coasts. Due to the reduced zonal extension of the South Atlantic Ocean, the BUS could be a non-negligible $\mathrm{N}$ source for the eastern part of the South Atlantic subtropical gyre by exporting $\mathrm{OM}$ and nutrients to the open ocean. In addition, the BUS presents one of the highest primary production of all EBUS (Carr, 2002; Carr and Kearns, 2003; Chavez and Messié, 2009). As with other EBUS, the trade winds maintain a horizontal pressure gradient along the coast associated with a coastal geostrophic current flowing towards the Equator. In the BUS, this coastal current is called the Benguela Current and contains cold and nutrient-rich waters. This system as well as the other EBUS is characterized by intense mesoscale activity which arises in the form of eddies, filaments, fronts and Rossby waves (e.g., Penven et al., 2001; Charria et al., 2006; Capet et al., 2008; Veitch et al., 2009; Gutknecht et al., 2010; Gruber et al., 2011). The BUS is the only EBUS bordered by two warm systems. To the south, the Agulhas Current leaks anticyclonic and cyclonic eddies carrying warm nutrient-depleted and cold nutrient-enriched waters, respectively (Boebel et al., 2003; Lutjeharms et al., 2003; Richardson et al., 2003; Schmid et al., 2003). To the north, the Angola cyclonic gyre or "Angola Dome" represents a pool of nutrient-enriched and oxygen-depleted waters (Monteiro et al., 2006; Mohrholz et al., 2008), which are advected poleward by the warm and saline Angola Current to the Angola-Benguela front $\left(15-18^{\circ} \mathrm{S}\right)$ before being relayed by the subsurface undercurrent in the northern part of the BUS (Mohrholz et al., 2008). This large-scale forcing associated with high local primary production and subsequent export production allows the maintenance of an $\mathrm{OMZ}$ in the northern part of the BUS, especially in the Namibian upwelling system between $20^{\circ} \mathrm{S}$ and $25^{\circ} \mathrm{S}$ (Monteiro et al., 2006, 2008 and 2011; Hutchings et al., 2009). In this 
OMZ, suboxic concentrations below $25 \mathrm{mmol} \mathrm{O}_{2} \mathrm{~m}^{-3}$ (or $\sim 0.5 \mathrm{~mL} \mathrm{O}_{2} \mathrm{~L}^{-1}$ ) are encountered in Walvis Bay (Monteiro et al., 2006, 2008), and even below the detection level for some periods of the year. During these extreme events, in addition to the respiratory barrier that affects zooplankton and fish (Ekau et al., 2010), sulfur emissions can occur with subsequent impacts on the mortality of commercial species (benthic communities such as demersal fish, lobster and shellfish; Lavik et al., 2008). Biogeochemical processes such as denitrification and anammox in this $\mathrm{OMZ}$ induce large losses of fixed N (Kuypers et al., 2005; Lavik et al., 2008), reaching more than $1 \mathrm{Tg} \mathrm{Nyr}^{-1}$ and hence could potentially mitigate the N export towards the South Atlantic subtropical gyre.

In our study of the Namibian upwelling system, the following questions are addressed: (1) What is the significance of the $\mathrm{N}$ export from the coastal upwelling area to the eastern part of the South Atlantic subtropical gyre? Does it sustain primary production in the open ocean as compared to the other $\mathrm{N}$ sources? (2) What are the losses of fixed $\mathrm{N}$ via denitrification/anammox in the OMZ off Namibia? (3) What are the $\mathrm{N}_{2} \mathrm{O}$ emissions to the atmosphere in the upwelling area? To answer these questions, we investigated the $\mathrm{N}$ fluxes in the Namibian upwelling system, and more specifically off the Walvis Bay area (between $22^{\circ} \mathrm{S}$ and $24^{\circ} \mathrm{S}$ ) where the $\mathrm{OMZ}$ is well developed. We use the Biogeochemical model for Eastern Boundary Upwelling Systems (BioEBUS), which represents the $\mathrm{N}$ cycle, one of the main limiting nutrients in the ocean, and takes into account the main processes linked with EBUS and associated OMZs. This model has been coupled to the 3-D hydrodynamic ROMS model over the Namibian upwelling system in the already validated "Namibian configuration" (Gutknecht et al., 2013). This coupled model and its summarized validation are presented in Sect. 2. The mean and eddy circulation as well as transport of nitrogen are described in Sect. 3.1. Then, $\mathrm{N}$ fluxes in the mixed layer of the Walvis Bay area are studied. Nitrogen export from the coastal area to the eastern part of the subtropical gyre is studied in Sect. 3.2. Losses of fixed $\mathrm{N}$ are estimated in Sect. 3.3, and $\mathrm{N}_{2} \mathrm{O}$ emissions to the atmosphere are considered in Sect. 3.4. Conclusions are presented in Sect. 4.

\section{Coupled physical/biogeochemical model}

\subsection{Hydrodynamic model: ROMS}

The hydrodynamic model used in this study is the Regional Ocean Modeling System (ROMS; Shchepetkin and McWilliams, 2003, 2005), in its version with the 2-way nesting capability (ROMS-AGRIF; Penven et al., 2006a; Debreu et al., 2012). It is a split-explicit and free-surface model that considers the Boussinesq and hydrostatic assumptions when solving the primitive equations. A specificity of ROMS comes from its vertical discretization with a sigma or topography-following stretched coordinate system. Ex- plicit lateral viscosity is zero everywhere in the simulated domain, except in the sponge layer at open boundaries where it increases smoothly on several grid points. It uses adaptive open boundary conditions combining outward radiations and nudging towards prescribed external boundary conditions (Marchesiello et al., 2001). The vertical turbulent closure is parameterized using the KPP boundary layer scheme (Large et al., 1994).

The SAfE (Southern African Experiment) configuration (Penven et al., 2006b; Veitch et al., 2009), a ROMS-AGRIF nested configuration of South Africa region, has been used to provide the initial and open boundary conditions of the Namibian configuration described in Gutknecht et al. (2013) and briefly reminded below.

\subsection{Biogeochemical model: BioEBUS}

The hydrodynamic ROMS model is coupled to BioEBUS (Gutknecht et al., 2013), a biogeochemical model developed for EBUS and associated OMZs. The evolution of a biological tracer concentration $C_{i}$ is determined by an advectivediffusive equation:

$$
\frac{\partial C_{i}}{\partial t}=-\nabla \cdot\left(\boldsymbol{u} C_{i}\right)+K_{\mathrm{h}} \nabla^{2} C_{i}+\frac{\partial}{\partial z}\left(K_{\mathrm{z}} \frac{\partial C_{i}}{\partial z}\right)+\operatorname{SMS}\left(C_{i}\right)
$$

The advection (with $\boldsymbol{u}$ the velocity vector) is represented by the first term on the right-hand side, the horizontal diffusion (with $K_{\mathrm{h}}$ the horizontal eddy diffusion coefficient) by the second term, and the vertical diffusion (with turbulent diffusion coefficient $K_{\mathrm{z}}$ ) by the third term. The last term represents the source minus sink (SMS) term due to biological activity.

BioEBUS is a nitrogen-based model (Fig. 1) derived from a $\mathrm{N}_{2} \mathrm{P}_{2} \mathrm{Z}_{2} \mathrm{D}_{2}$ model (Koné et al., 2005), taking into account the main planktonic communities and their specificities in the Benguela upwelling ecosystem as well as the main processes linked with EBUS and associated OMZs. It was recently adjusted and validated in Gutknecht et al. (2013) using available satellite and in situ data in the northern part of the BUS. In this model, phytoplankton and zooplankton are split into small $\left(\mathrm{P}_{\mathrm{S}}\right.$ and $\mathrm{Z}_{\mathrm{S}}$ : flagellates and ciliates, respectively) and large $\left(\mathrm{P}_{\mathrm{L}}\right.$ and $\mathrm{Z}_{\mathrm{L}}$ : diatoms and copepods, respectively) organisms. Detritus are also separated into small and large particulate compartments $\left(\mathrm{D}_{\mathrm{S}}\right.$ and $\left.\mathrm{D}_{\mathrm{L}}\right)$. A semilabile dissolved organic nitrogen (DON) compartment was added since DON can be an important reservoir of OM and can potentially play an important role in supplying nitrogen or carbon from the coastal region to the open ocean (Huret et al., 2005). The pool of dissolved inorganic nitrogen is split into nitrate $\left(\mathrm{NO}_{3}^{-}\right)$, nitrite $\left(\mathrm{NO}_{2}^{-}\right)$and ammonium $\left(\mathrm{NH}_{4}^{+}\right)$species to have a detailed description of the microbial loop: ammonification/nitrification processes under oxic conditions, and denitrification/anammox processes under suboxic conditions (Yakushev et al., 2007). These processes are directly oxygen-dependent, so an oxygen $\left(\mathrm{O}_{2}\right)$ equation was 


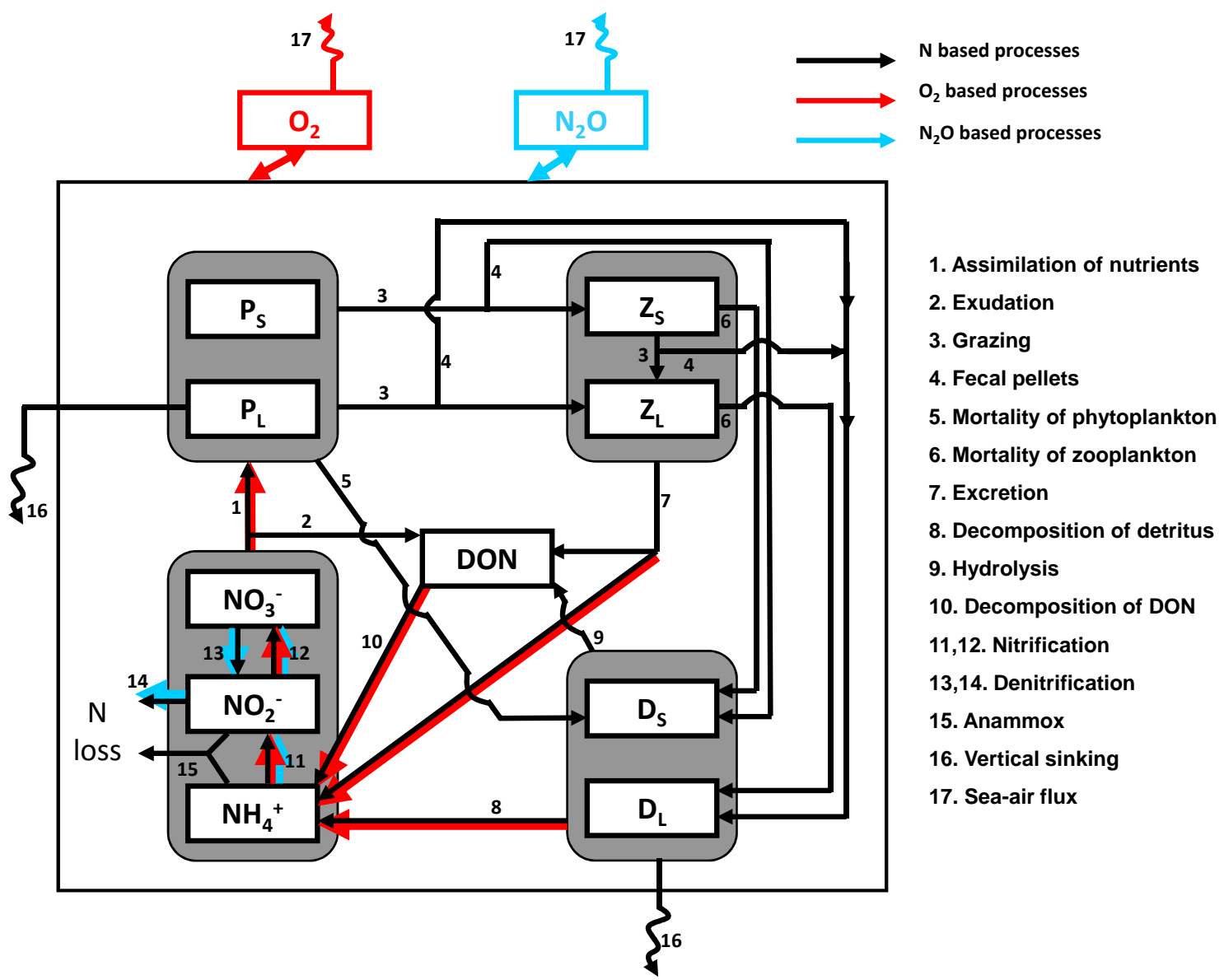

Fig. 1. Interactions between the different compartments of the BioEBUS model. Black arrows represent the nitrogen-dependent processes, red arrows the oxygen-dependent processes, and blue arrows the processes linked with $\mathrm{N}_{2} \mathrm{O}$ production. To simplify the representation of all interactions between variables, arrows from or to a grey rectangle act on all variables included in this grey rectangle. For example, the arrow between nutrients and phytoplankton (assimilation) is a simplification of 6 interactions: $\mathrm{NO}_{3}^{-}$to $\mathrm{P}_{\mathrm{S}}, \mathrm{NO}_{3}^{-}$to $\mathrm{P}_{\mathrm{L}}, \mathrm{NO}_{2}^{-}$to $\mathrm{P}_{\mathrm{S}}, \mathrm{NO}_{2}^{-}$to $\mathrm{P}_{\mathrm{L}}$, $\mathrm{NH}_{4}^{+}$to $\mathrm{P}_{\mathrm{S}}, \mathrm{NH}_{4}^{+}$to $\mathrm{P}_{\mathrm{L}}$.

also introduced in BioEBUS with the source term (photosynthesis), the sink terms (zooplankton respiration, bacteria remineralisation) as well as the sea-air $\mathrm{O}_{2}$ fluxes following Peña et al. (2010) and Yakushev et al. (2007). To complete this nitrogen-based model, nitrous oxide $\left(\mathrm{N}_{2} \mathrm{O}\right)$ was introduced using the parameterization of Suntharalingam et al. (2000, 2012). It allows determining the $\mathrm{N}_{2} \mathrm{O}$ production under oxygenated conditions and at low-oxygen levels, mimicking the $\mathrm{N}_{2} \mathrm{O}$ production from nitrification and denitrification processes. The SMS terms of BioEBUS as well as parameter values are described in detail in Gutknecht et al. (2013).

\subsection{The Namibian configuration}

The Namibian configuration spans from $5^{\circ} \mathrm{E}$ to $17^{\circ} \mathrm{E}$ and $19^{\circ} \mathrm{S}$ to $28.5^{\circ} \mathrm{S}$. It has a horizontal resolution of $1 / 12^{\circ}$, a vertical grid of 32 sigma-levels stretched so that nearsurface resolution increases, and a smoothed bottom topog- raphy from 1' GEBCO product (General Bathymetric Chart of the Oceans: http://www.gebco.net).

As described in Gutknecht et al. (2013), initial and open boundary conditions for temperature, salinity, free surface and the velocity (zonal and meridional components) are provided by the outputs of the SAfE configuration (Veitch et al., 2009). We applied the same ocean-atmosphere forcing as Veitch et al. (2009). A QuikSCAT monthly climatological wind stress is used to force the model at the surface. Surface heat and salt fluxes are provided by COADS-derived monthly climatology (Da Silva et al., 1994). An air-sea feedback parameterization term, using the $9 \mathrm{~km}$ Pathfinder climatological sea surface temperature (Casey and Cornillon, 1999), is added to the surface heat flux to avoid model sea surface temperature drift (Barnier et al., 1995; Marchesiello et al., 2003). A similar correction scheme as in Veitch et al. (2009) is used for sea surface salinity because of the paucity of evaporationprecipitation forcing fields. 
For biogeochemistry, initial and open boundary conditions for $\mathrm{NO}_{3}^{-}$and $\mathrm{O}_{2}$ concentrations are provided by the CSIRO Atlas of Regional Seas (CARS, 2006). Phytoplankton is a function of Chl $a$ derived from SeaWiFS climatology. $\mathrm{N}_{2} \mathrm{O}$ is a function of $\mathrm{O}_{2}$ using the parameterization of Suntharalingam et al. (2000, 2012). For other biogeochemical tracers, initial and lateral boundary conditions are established using a vertical constant or exponential profile based on Koné et al. (2005). Please see Gutknecht et al. (2013) for more details.

The simulation is run for a total of $19 \mathrm{yr}$. A physical spin-up is performed over $7 \mathrm{yr}$ as the model needs a few years to reach a stable annual cycle. Then the coupled phys$\mathrm{ical} /$ biogeochemical model is run for 12 years. The last 8 years (years 12-19) of simulation are used to analyze the model performance and the nitrogen fluxes.

\subsection{Performance of the coupled model}

A detailed analysis of the coupled model performance is presented in Gutknecht et al. (2013), using annual and seasonal climatologies and recent in situ data sampled in the BUS. Here, a short validation is summarized in Fig. 2 and Table 1. Temperature, salinity, and density fields are compared to CARS database (2009), oxygen and nitrate concentrations to CARS database (2006). Chlorophyll $a$ concentrations are compared to SeaWiFS (McClain et al., 1998; O'Reilly et al., 2000) and World Ocean Atlas (WOA) 2001 (Conkright et al., 2002) climatologies. Statistics are also performed between the model and recent in situ data off Namibia. A Taylor diagram (Fig. 2) summarizes the statistics between simulated fields and data for which the model is interpolated onto the observed data locations (Taylor, 2001). For other fields (nitrite, ammonium, primary production, and zooplankton), data are more scattered, so the model/data comparison is presented in Table 1. The performance of the coupled model is studied over the whole 3-D Namibian configuration.

\subsubsection{Physical properties}

Simulated fields and climatological database follow the same seasonal cycle. During winter season, trade winds intensify and simulated temperature, salinity and density isocontours rise to the surface along Namibian coast, as a signature of the coastal upwelling. Sea surface temperatures vary between $12-13^{\circ} \mathrm{C}$ in winter and $17-18^{\circ} \mathrm{C}$ in summer. A maximum sub-surface salinity coming from the strong poleward undercurrent in austral summer progressively upwells to the surface with intensification of the trade winds in winter (Gutknecht et al., 2013).

On annual mean, correlation coefficients are above 0.99 for the three physical variables (Fig. 2). The normalized standard deviations are between 0.88 and 1.01 , and the normalized centered pattern RMS differences are less than 0.17 (or a RMS difference of $0.51^{\circ} \mathrm{C}, 0.063$, and $0.1 \mathrm{~kg} \mathrm{~m}^{-3}$ for tem- perature, salinity, and density, respectively). Our climatological configuration succeeds in simulating the annual mean and seasonal cycle of physical properties. Statistics between simulated fields and in situ data for specific years are less satisfactory (Fig. 2) as the important interannual variability observed off Namibia is not reproduced in this climatological simulation.

\subsubsection{Oxygen and nutrient distribution}

Simulated and climatological data sets follow the same seasonal cycle. Deoxygenated waters are shallower in austral summer and oxygenated surface layer is thicker during austral winter. These changes are due to the alternative dominance of the poleward undercurrent in austral summer and the coastal Benguela Current in austral winter (Gutknecht et al., 2013). The wind-driven upwelling of nitrate-rich waters in austral winter is also correctly simulated.

On annual mean, correlation coefficients are 0.94 and 0.99 for oxygen and nitrate, respectively (Fig. 2). The normalized centered pattern RMS difference are 0.35 and 0.16 (or a RMS difference of $16.5 \mathrm{mmol} \mathrm{O}_{2} \mathrm{~m}^{-3}$ and $1.82 \mathrm{mmol} \mathrm{N} \mathrm{m}^{-3}$ ), and the normalized standard deviation are 0.9 and 1.01 , respectively. As for the physical variables, the statistical metrics highlight an important variability between the in situ data used for comparison with the model.

Simulated nitrite and ammonium distribution present a sub-surface maximum ( $\sim 50 \mathrm{~m}$ depth) above the continental shelf, with concentrations in the range of in situ concentrations reported in the Namibian upwelling system during AHAB1, Galathea and AMT6 cruises (Table 1). However, we do not have enough in situ measurements to really conclude on the performance of the model in simulating the vertical distribution and seasonal cycle of nitrite and ammonium off Namibia.

\subsubsection{Chlorophyll $a$ and primary production}

The model simulates minimum Chl $a$ during winter. Some weeks after the maximum upwelling, Chl $a$ increases up to maximum values in summer. This simulated seasonal cycle is in good agreement with the one issue from the SeaWiFS climatology (Gutknecht et al., 2013). Simulated and satellite data (Fig. 2) present a correlation coefficient of 0.91 , a normalized standard deviation lower than 1 highlighting an underestimation of the simulated $\mathrm{Chl} a$ variance, on spatial and temporal scales, and a normalized centered pattern RMS difference to 0.51 (or a RMS difference less than $0.58 \mathrm{mg} \mathrm{Chl} \mathrm{m}^{-3}$ ). Better results are obtained when simulated Chl $a$ is compared with SeaWiFS data (described above) than with surface WOA 2001 data (Fig. 2) due to the biomass temporal changes observed in EBUS (Gutknecht et al., 2013). In our modeling experiment, the Namibian system appears to be twice more productive in summer than in winter, in agreement with Barlow et al. (2009) who described the 
Table 1. Summary of comparison between simulated and in situ data for nitrite, ammonium, primary production (integrated over the euphotic zone), and zooplankton (time series at $23^{\circ} \mathrm{S}$ integrated over $200 \mathrm{~m}$ depth).

\begin{tabular}{lll}
\hline & Model & Data \\
\hline $\begin{array}{l}\text { Nitrite } \\
\left(\mathrm{mmol} \mathrm{N} \mathrm{m}^{-3}\right)\end{array}$ & $0.002-0.37$ & $\begin{array}{l}\text { from 0.01 to 1 } \\
\text { (AHAB1, Galathea, AMT 6 cruises) }\end{array}$ \\
$\begin{array}{l}\text { Ammonium } \\
\left(\mathrm{mmol} \mathrm{N} \mathrm{m}^{-3}\right)\end{array}$ & $0.006-0.56$ & $\begin{array}{l}<0.3 \text { to } 4 \\
\text { (AHAB1, Galathea, AMT 6 cruises) }\end{array}$ \\
$\begin{array}{l}\text { Annual primary } \\
\text { production } \\
\left(10^{2} \mathrm{~g} \mathrm{C} \mathrm{m}^{-2} \mathrm{yr}^{-1}\right)\end{array}$ & $5 \pm 0.05$ & $\begin{array}{l}4.3 \text { (Brown et al., 1991) } \\
7.6 \text { (Ware, 1992) }\end{array}$ \\
& & 9.5 (Carr, 2002) \\
& $5.1 \pm 0.6$ (Tilstone et al., 2009; AMT data) \\
$\begin{array}{l}\text { Mesozooplankton } \\
\left(\mathrm{mmol} \mathrm{N} \mathrm{m}{ }^{-2}\right)\end{array}$ & $21.5-120$ & $21.5-150$ (KA08) \\
\hline
\end{tabular}

AHAB1 cruise: R/V Alexander von Humboldt cruise in January $2004\left(22-27^{\circ} \mathrm{S}, 12-15^{\circ} \mathrm{E}\right)$.

Galathea: Danish Galathea expedition in October 2006 (courtesy of L. L. Søerensen) (20-28.5 ${ }^{\circ} \mathrm{S}$,

$\left.11.5-15.5^{\circ} \mathrm{E}\right)$.

AMT 6 cruise: Atlantic Meridional transect 6 cruise in May 1998 (Aiken, 1998; Aiken and Bale, 2000;

Aiken et al., 2000) $\left(20-27^{\circ} \mathrm{S}, 11.5^{\circ}-15^{\circ} \mathrm{E}\right)$.

KA08: Kreiner and Ayon (2008) $\left(23^{\circ} \mathrm{S}, 13.5-14.2^{\circ} \mathrm{E}\right)$.

same seasonal cycle. Annual primary production simulated by the coupled model is $5 \pm 0.05 \times 10^{2} \mathrm{~g} \mathrm{C} \mathrm{m}^{-2} \mathrm{yr}^{-1}$, in the range of previous estimates made in the BUS: $3.7 \times 10^{2}$ to $9.5 \times 10^{2} \mathrm{~g} \mathrm{C} \mathrm{m}^{-2} \mathrm{yr}^{-1}$ (Brown et al., 1991; Ware, 1992; Carr, 2002; Tilstone et al., 2009) (Table 1). Spatio-temporal variability of $\mathrm{Chl} a$ and primary production is reasonably well captured in our modeling experiment (Gutknecht et al., 2013).

\subsubsection{Zooplankton}

Seasonal cycle of zooplankton follows that of $\mathrm{Chl} a$ with a time lag of 3 to 8 weeks necessary for zooplankton to react to the phytoplanktonic biomass increase (Postel et al., 1995). Simulated copepod biomass (integrated over 200-m depth) varies between 21.5 and $120 \mathrm{mmol} \mathrm{N} \mathrm{m}^{-2}$, with a maximum of copepod biomass during summer-early fall, located between 10 and 50 nautical miles off the coast. In situ data sampled between 2000 and 2007 (Kreiner and Ayon, 2008) present the same seasonal cycle, with biomass varying between $21.5 \mathrm{mmol} \mathrm{N} \mathrm{m}^{-2}$ and a maximum of $150 \mathrm{mmol} \mathrm{N} \mathrm{m}^{-2}$ usually observed during the first part of the year (summer-early fall). As described in details by Gutknecht et al. (2013), both amplitude and spatio-temporal location of the copepod biomass maximum appear well simulated.

\subsection{5 $\quad \mathrm{N}_{2} \mathrm{O}$ distribution}

During the FRS Africana cruise in December 2009, in situ $\mathrm{N}_{2} \mathrm{O}$ concentrations (the first in situ measurements made off Namibia) reached up to $40 \times 10^{-3}$ mmol $\mathrm{N}_{2} \mathrm{O}$ $\mathrm{m}^{-3}$ in oxygen-depleted waters onto the shelf and shelf break. Alongshore winds were strong enough to make the nutrient-rich and oxygen-depleted waters intersect the surface along the coast of Walvis Bay (Mohrholz et al., 2009, in Cruise Report from Verheye and Ekau, 2009). For climatological December month, our coupled model also simulates an upwelling along the coast of Namibia, but monthly averaged $\mathrm{N}_{2} \mathrm{O}$ concentrations do not exceed $30 \times 10^{-3} \mathrm{mmol} \mathrm{N}_{2} \mathrm{O} \mathrm{m}^{-3}$ on the bottom waters of the continental slope. However, the relation between $\mathrm{O}_{2}$ and $\mathrm{N}_{2} \mathrm{O}$ concentrations seems to be correctly reproduced by the model (Gutknecht et al., 2013). More in situ measurements are really needed to validate our fields at low oxygen concentrations.

As summarized here and detailed in Gutknecht et al. (2013), the model realistically represents the annual mean and the seasonal cycle of temperature, salinity, density, nitrate and oxygen concentrations. Vertical gradients of simulated oxygen and nitrate concentrations as well as horizontal distributions provide satisfying results. Simulated nitrite and ammonium concentrations are within the range of available in situ data. Additionally, spatial pattern and seasonal cycle of chlorophyll $a$ concentrations, primary production and zooplankton biomass are well captured in our climatological modeling experiment, although the important variability observed in in situ data for specific years makes the analysis delicate. Finally, simulated and in situ $\mathrm{N}_{2} \mathrm{O}$ concentrations have similar values, and the relation linking $\mathrm{O}_{2}$ to $\mathrm{N}_{2} \mathrm{O}$ seems to follow the same trend. 


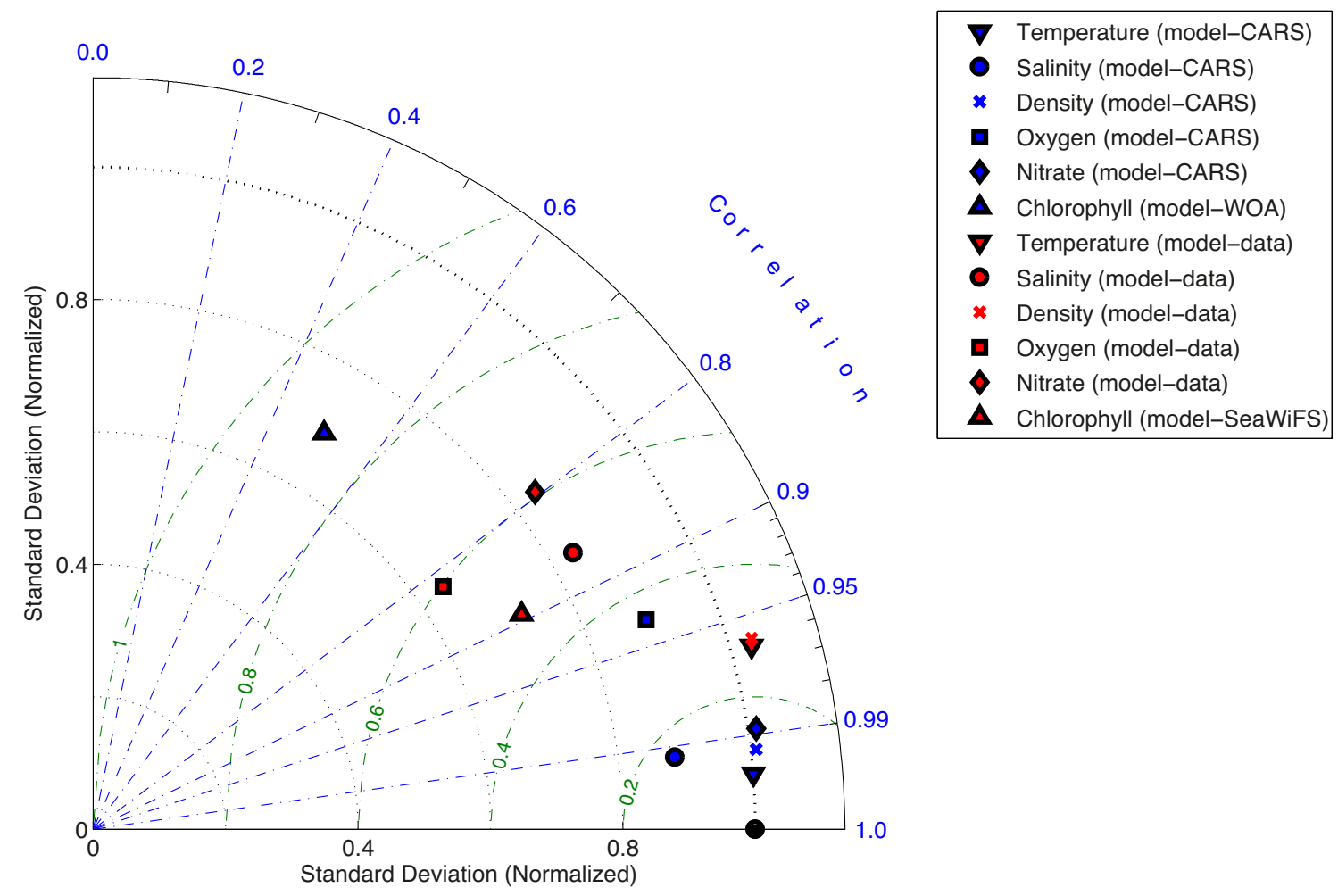

Fig. 2. Taylor diagram for temperature, salinity, density, oxygen, nitrate and chlorophyll concentrations. The radial distance from the origin is proportional to the standard deviation of a pattern (normalized by the standard deviation of the data: in situ, satellite or climatological data). The green dashed lines measure the distance from the reference point (the data; black filled circle in the diagram) and indicate the RMS error. The correlation between both fields is given by the azimuthal position of the test field. The statistics use data from annual climatologies (CARS 2006 and 2009, WOA 2001 and SeaWiFS) and from various cruises (summarized here as "in situ"; see details in Gutknecht et al., 2013). For comparison with annual climatologies, simulated fields were averaged using the 8 last years of simulation. For comparison with in situ data, simulated fields were monthly averaged, and we used the monthly mean corresponding to the cruise (see details in Gutknecht et al., 2013).

\section{Nitrogen fluxes in the Walvis Bay area}

The positive evaluation of the model performance for the mean state and seasonal cycle allows for us to investigate the nitrogen $(\mathrm{N})$ fluxes in the Walvis Bay area. This section starts with a description of the mean and eddy circulation and transport of the main nitrogen form responsible for high productivity in EBUS: the nitrate. Then, we focus on $\mathrm{N}$ fluxes in the mixed layer in order to answer the main questions outlined in the introduction section. First, total $\mathrm{N}$ offshore export is estimated in the mixed layer at the $10^{\circ} \mathrm{E}$ boundary, and represents a possible $\mathrm{N}$ source originating from the upwelling area to sustain primary production in the eastern part of the South Atlantic subtropical gyre. Secondly, export production across the mixed layer depth is estimated, and represents an OM supply to oxygen-consuming processes, leading to suboxic conditions and loss of fixed N. Finally, we evaluate the role of the studied area as a $\mathrm{N}_{2} \mathrm{O}$ source for the atmosphere. To address these points, the full $\mathrm{N}$ budget is investigated in the mixed layer ( $50 \mathrm{~m}$ depth on average) of the Walvis Bay area, using the 8 last years of simulation. The Walvis Bay area is defined as the area between $22^{\circ} \mathrm{S}$ and $24^{\circ} \mathrm{S}$, and from the coast to $10^{\circ} \mathrm{E}$, with a surface of $10.3 \times 10^{4} \mathrm{~km}^{2}$. The budget highlights the different important pathways for the physical and biogeochemical $\mathrm{N}$ transfers in the Walvis Bay area. Particular attention is given to the use and interpretation of diagnostics in sigma vertical coordinates.

\subsection{Circulation, nitrate transport and role of mesoscale activity}

The circulation in the Walvis Bay area (Fig. 3) is typical of EBUS (Marchesiello et al., 2003). Alongshore trade winds generate horizontal offshore Ekman transport and upwelling of deep, cold and nitrate-rich waters along the coast. The coastal upwelling process drives an alongshore, equatorward coastal jet (the coastal part of the Benguela Current) and a poleward undercurrent in geostrophic balance (nearshore positive wind stress curl also participates in the poleward flow). In the offshore region, negative wind stress curl yields the offshore Benguela Current (in Sverdrup balance), as well as surface convergence and downwelling. To compensate for 
a)

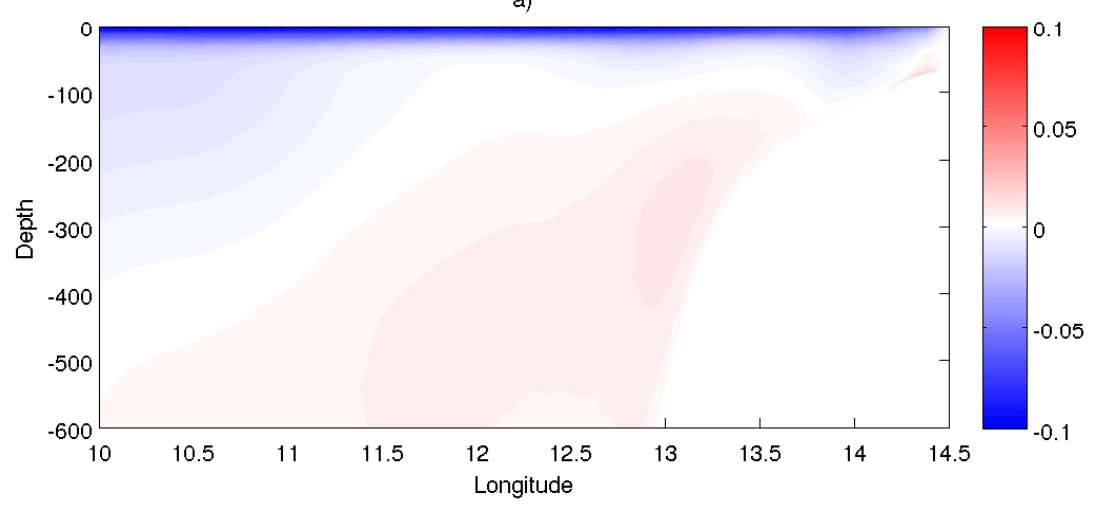

b)

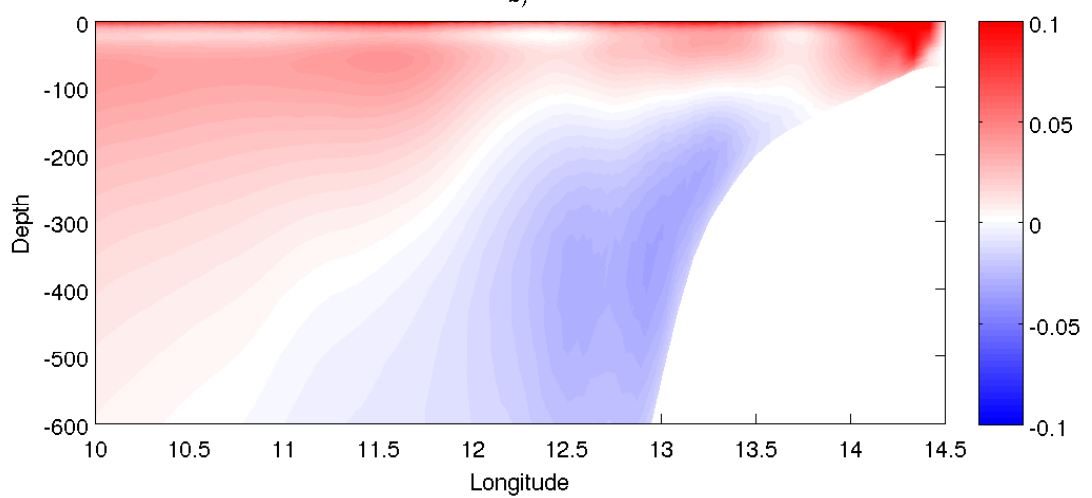

c)

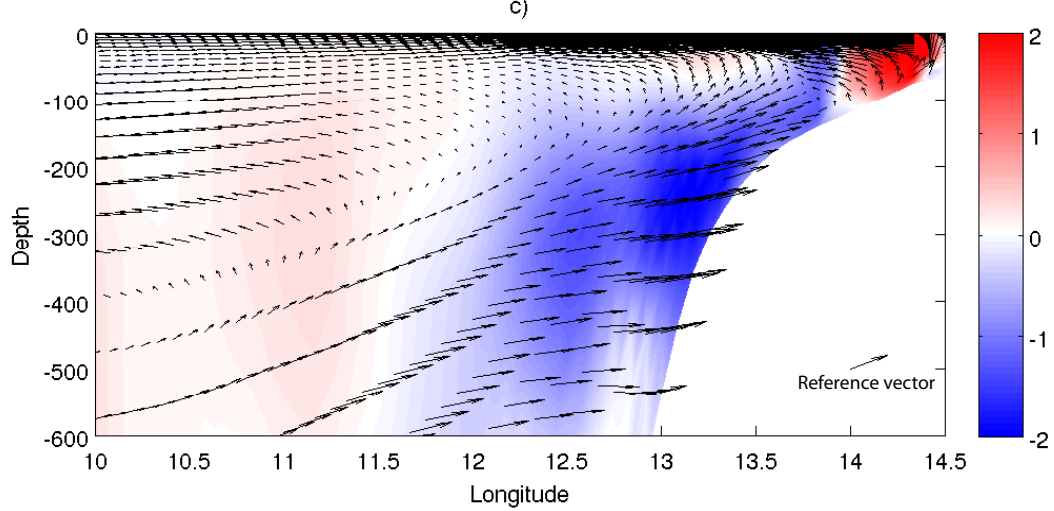

Fig. 3. (a) Zonal component of velocity ( $\mathrm{m} \mathrm{s}^{-1}$; positive values indicate eastward direction). (b) Meridional component of velocity ( $\mathrm{m} \mathrm{s}^{-1}$; positive values indicate northward direction). (c) Zonal and vertical component of total nitrate flux (vectors) and meridional component of total nitrate flux divergence (in color; positive sign represents a nitrate source and negative a sink) (mmol $\mathrm{N} \mathrm{m}^{-2} \mathrm{~s}^{-1}$ ). The reference vector indicates $0.2 \mathrm{mmol} \mathrm{N} \mathrm{m}^{-2} \mathrm{~s}^{-1}$ on the $\mathrm{x}$-axis and $0.2 \times 10^{-3} \mathrm{mmol} \mathrm{N} \mathrm{m}^{-2} \mathrm{~s}^{-1}$ on the $\mathrm{z}$-axis. Fields are $8 \mathrm{yr}$ means, averaged between $22^{\circ} \mathrm{S}$ and $24^{\circ} \mathrm{S}$.

coastal Ekman divergence, a return flow develops at depth, balanced by friction in the bottom Ekman layer and by alongshore pressure gradients in the interior.

The surface layer (here considered as the mixed layer; Fig. 4) is mainly supplied in nitrate by local upwelling; vertical advection contributes $67 \%$ of nitrate inputs for the mixed layer. The Benguela Current advects nitrates coming from the intense Lüderitz upwelling cell south of Walvis Bay, and also represents a net source of nitrate for the studied area (contribution of $18 \%$ ), with a maximum input in the first $50 \mathrm{~km}$ from the coast (Fig. 3c). The higher inflow at the southern boundary $\left(24^{\circ} \mathrm{S}\right.$; $+20.2 \pm 1.3 \times 10^{10} \mathrm{~mol} \mathrm{~N} \mathrm{yr}^{-1}$ ) than outflow at the northern boundary $\left(22^{\circ} \mathrm{S} ;-16.1 \pm 1 \times 10^{10} \mathrm{~mol} \mathrm{~N} \mathrm{yr}^{-1}\right)$ is due to nitrate sink by biology and offshore advection (Fig. 4). Vertical diffusion is also noticeable with a $15 \%$ contribution to nitrate 


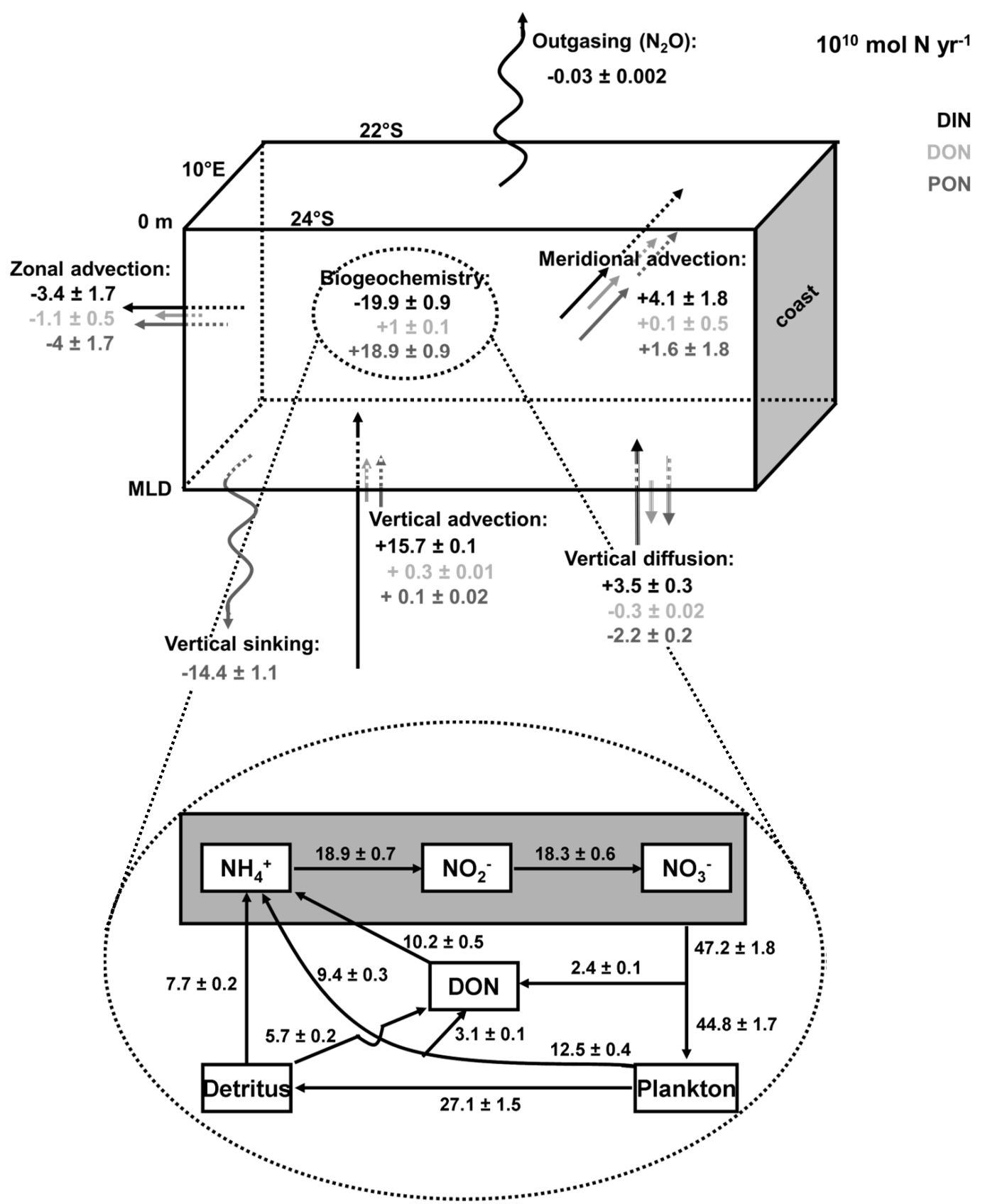

Fig. 4. Full nitrogen budget in the mixed layer $\left(10^{10} \mathrm{~mol} \mathrm{~N} \mathrm{yr}^{-1}\right)$ with zoom on biogeochemical fluxes. Fluxes of DIN are indicated in black,

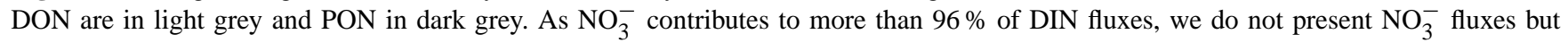
assume them equal to DIN fluxes. Fluxes are $8 \mathrm{yr}$ means, averaged between $22^{\circ} \mathrm{S}$ and $24^{\circ} \mathrm{S}$.

inputs in the mixed layer. At depth, the upwelling return flow supplies the Ekman divergence. However, the poleward undercurrent flowing from Angola represents a net sink of nitrate for the studied area with maximum loss on the shelf break as the poleward nitrate flux at $24^{\circ} \mathrm{S}$, carrying away some of the input by the return flow, is higher than the poleward nitrate flux at $22^{\circ} \mathrm{S}$ (Fig. 3c).
Nitrate advection is composed by mean flow (with Ekman and geostrophic components) and eddy contribution. While mesoscale processes are known to significantly increase local nutrient input in the surface layer and favor photosynthesis in the open ocean, it was recently suggested that they have an opposite effect in EBUS (Rossi et al., 2008, 2009; Gruber et al., 2011). Gruber et al. (2011) confirm the reduction of biological production due to mesoscale eddy activity. They 
show that eddies induce a cross-shore advection that tends to oppose that of the upwelling cell resulting in a relative loss of nutrients in the nearshore region compensated by offshore transport at depth. This description is consistent with our own estimation of the eddy impact on nitrate distribution of the Walvis Bay area. We computed 3-D eddy-induced transports in the whole region of interest using the classical Reynolds decomposition. The temporal mean for each component (zonal, meridional and vertical) is decomposed in a mean flow and eddy contribution. For example, for zonal advection, we obtain the following:

$$
\frac{\overline{\partial\left(u \mathrm{NO}_{3}^{-}\right)}}{\partial x}=\frac{\partial\left(\bar{u} \overline{\mathrm{NO}_{3}^{-}}\right)}{\partial x}+\overline{\frac{\partial\left(u^{\prime} \mathrm{NO}_{3}^{-\prime}\right)}{\partial x}} .
$$

The first term on the right-hand side of the equation represents the mean flow; the second term, the eddy contribution. $\bar{u}$ and $\overline{\mathrm{NO}_{3}^{-}}$are the $8 \mathrm{yr}$ mean of $u$ and $\mathrm{NO}_{3}^{-}$. The fluctuant parts $\left(u^{\prime}=u-\bar{u}\right.$ and $\left.\mathrm{NO}_{3}^{-\prime}=\mathrm{NO}_{3}^{-}-\overline{\mathrm{NO}_{3}^{-}}\right)$are determined using 3 day mean outputs (filtering out high-frequency modes such as inertial oscillations).

Integrated over the whole water column, total nitrate advection over the shelf is governed by the mean flow, but the mean transport is largely compensated by eddy contributions over the slope region (Fig. 5). The mean flow acts as a net source of nitrate due to upwelling and Ekman transport from the shelf. On other hand, the eddy contribution represents a net loss of nitrate in the nearshore region due to eddy diffusion and advection, acting against the wind-driven upwelling (Fig. 6). In agreement with Gruber et al. (2011) and Colas et al. (2013), eddy advection below the mixed layer is driven by a shoreward eddy-induced (bolus) flow balanced at depth by an offshore flow (represented by a bolus streamfunction in Fig. 6). In the mixed layer, submesoscale eddy advection associated with frontal processes (Colas et al., 2013) provides a more complicated pattern with strong vertical but weak lateral contribution to eddy transports (not shown). Eddy diffusion (as opposed to eddy advection) is the dominant mesoscale process in the mixed layer. It has maximum intensity in the coastal transition zone (between coastal and offshore regions) and tends to diffuse nitrate concentrations downgradient across the slope region (decreasing $\mathrm{N}$ nearshore and increasing it offshore). Therefore, eddy diffusion contributes to the offshore export of nutrients as it removes them from the nearshore region; but as a whole, eddy transport depletes the reservoir of nutrient available in the upwelling process (akin to the "nutrient leakage" process of Gruber et al., 2011). To confirm the role of eddies on the vertical distribution of nitrates, a non eddy-resolving simulation is conducted as in Gruber et al. (2011) by linearization of the momentum equation. In this case, cancellation of the nonlinear advection terms $(\boldsymbol{u} \cdot \nabla \boldsymbol{u})$ prevents dynamical instabilities that develop into mesoscale eddies. The resulting nitrate deficit (up to $-50 \%$ ) between eddy-resolving and non eddy-resolving simulations confirms a coastal nitrate loss due to eddy activity (Fig. 7). For the Walvis Bay area, eddy activity leads to a $17 \%$ decrease in primary production. This is a significant decrease and should be accounted for in global estimations of primary production.

\subsection{Nitrogen offshore export}

In the surface layer, vertical and meridional nutrient sources are mainly consumed by the phytoplankton. Indeed, phytoplankton consumes $85 \%$ of nutrients, the rest being exported offshore (Fig. 4). Also, the local ecosystem produces a large amount of PON; only $8 \%$ of PON sources in the Walvis Bay area come from horizontal advection. Here, the PON term includes all particulate OM forms, inert and alive (so both classes of detritus, zooplankton and phytoplankton). Large detritus mainly sink by gravity (see following section) and the other particulate OM forms are exported offshore and vertically diffused. At the $10^{\circ} \mathrm{E}$ boundary, nitrate contributes to $40 \%$ of the total $\mathrm{N}$ offshore export in the mixed layer, and PON to $47 \%$, mainly under the form of plankton (diatoms, ciliates and copepods). DON is less important for the offshore export $(13 \%)$ due to active decomposition in the mixed layer (Fig. 4). The total $\mathrm{N}$ offshore export is estimated to $8.5 \pm 3.9 \times 10^{10} \mathrm{~mol} \mathrm{~N} \mathrm{yr}^{-1}$ for the first $50 \mathrm{~m}$ depth of the water column at $10^{\circ} \mathrm{E}$ off the Walvis Bay area (Fig. 4), $50 \%$ being explained by Ekman transport on $8 \mathrm{yr}$ mean. As investigated in the previous section, mesoscale activity impacts the nitrate distribution in the studied area. In the mixed layer, eddy transport contributes to the $\mathrm{N}$ offshore export from the upwelling area to the open ocean. At the $10^{\circ} \mathrm{E}$ boundary, eddies contribute to $20 \%$ of total $\mathrm{N}$ offshore export on $8 \mathrm{yr}$ mean (from $4 \%$ to $38 \%$ on annual mean), playing a significant role in supplying the subtropical gyre with nitrogen. To our knowledge, there is no other quantitative estimation of the mesoscale impact on nitrogen cross-shore exports in EBUS.

\section{Potential extrapolation to the whole Benguela}

Considering a horizontal surface for the South Atlantic subtropical gyre of $9 \times 10^{6} \mathrm{~km}^{2}$ (based on the South Atlantic Subtropical Gyral Province from Longhurst, 1998), N total offshore export of the Walvis Bay area is equivalent to $0.01 \pm 0.004 \mathrm{~mol} \mathrm{~N} \mathrm{~m}^{-2} \mathrm{yr}^{-1}$ for this gyre. Assuming the same contribution for the entire BUS $\left(18^{\circ} \mathrm{S}\right.$ to $35^{\circ} \mathrm{S}$ with $10^{\circ} \mathrm{E}$ offshore, or $10.5 \times 10^{5} \mathrm{~km}^{2}$ ) as for the Walvis Bay area, the $\mathrm{N}$ source for the subtropical gyre would correspond to $0.1 \pm 0.04 \mathrm{~mol} \mathrm{~N} \mathrm{~m}^{-2} \mathrm{yr}^{-1}$. Compared to the other possible $\mathrm{N}$ sources sustaining primary production in the subtropical gyre (Table 2), the BUS appears as a significant $\mathrm{N}$ source for the eastern part of the South Atlantic subtropical gyre, at least one order of magnitude higher than the other reported sources. However, the extrapolation made here certainly represents an upper limit to the $\mathrm{N}$ export from the BUS to the subtropical gyre as Walvis Bay is particularly productive. 


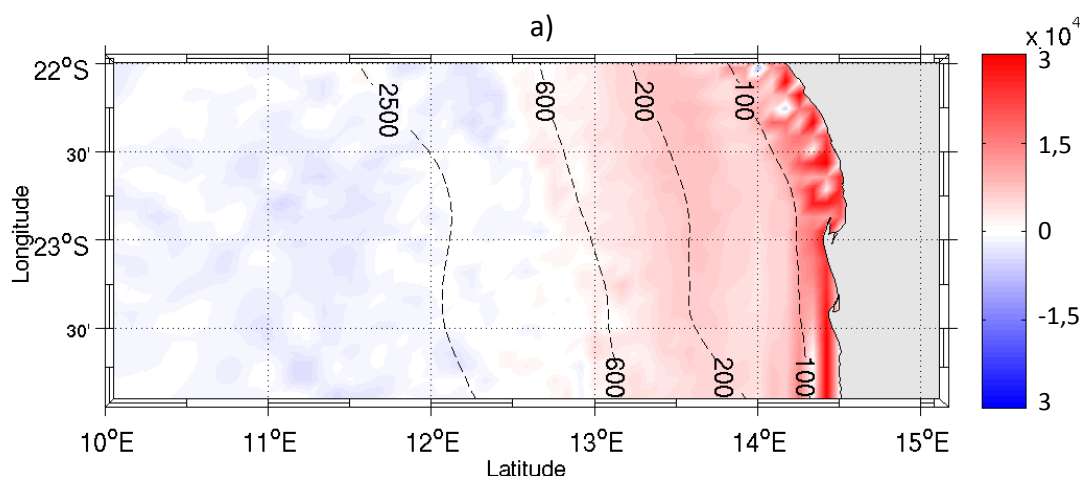

b)

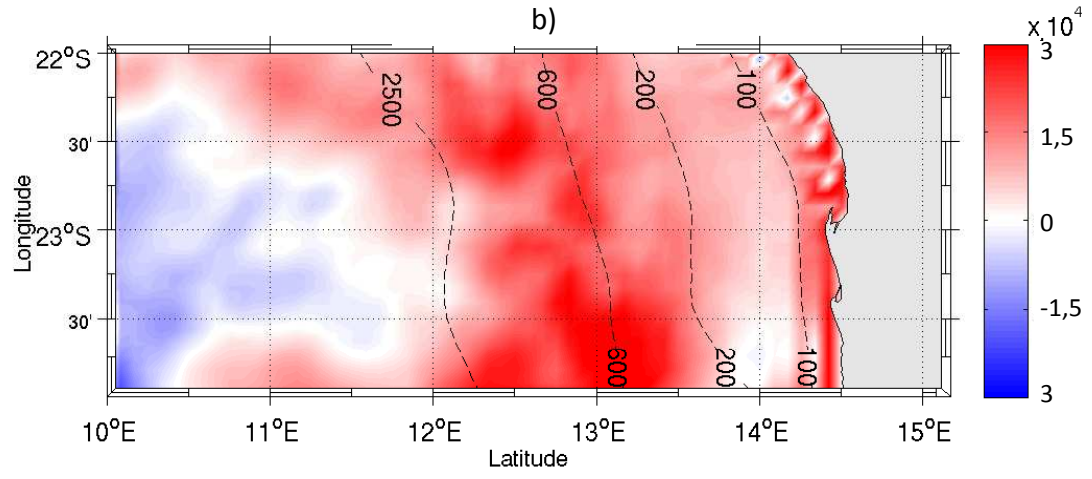

c)

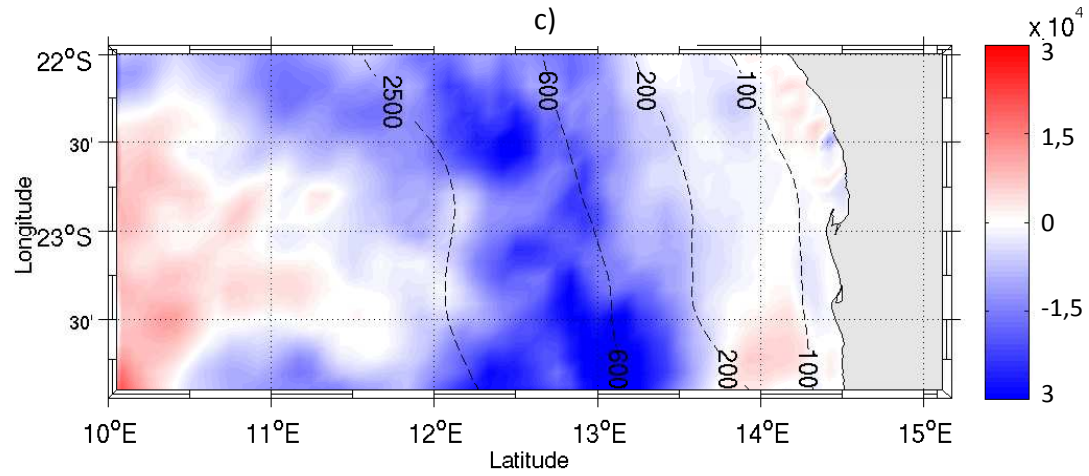

Fig. 5. Sum of zonal, meridional and vertical components of nitrate advection terms ( $m m o l ~ \mathrm{~N} \mathrm{~m}^{-2} \mathrm{~s}^{-1}$ ): total (a), mean (b), and eddy (c) contributions. Advections terms are $8 \mathrm{yr}$ averages, integrated over the whole water column. Positive sign represents a nitrate source and, negative sign, a sink.

This $\mathrm{N}$ offshore export is likely to sustain primary production in the open ocean by supplying new nitrogen for the subtropical gyre. Annual mean primary production is estimated to about $0.27 \mathrm{~g} \mathrm{C} \mathrm{m}^{-2} \mathrm{~d}^{-1}$, or $1.2 \mathrm{~mol} \mathrm{~N} \mathrm{~m}^{-2} \mathrm{yr}^{-1}$ for the South Atlantic subtropical gyre using production model and satellite chlorophyll data (Gregg et al., 2003). Using a $f$ ratio of 0.3 in the South Atlantic subtropical gyre, following the study of Yool et al. (2007) (mean between the classical (0.5) and new (0.1) $f$-ratio in their study), new primary production represents $0.36 \mathrm{~mol} \mathrm{~N} \mathrm{~m}^{-2} \mathrm{yr}^{-1}$. Our results suggest that $\mathrm{N}$ offshore export from the BUS to the open ocean represents a major source of $\mathrm{N}$ for the subtropical gyre, potentially contributing to $28 \%$ of the new primary production estimated for the South Atlantic subtropical gyre. Integrating the surface layer up to $100 \mathrm{~m}$ depth, BUS contributes to $42 \%$ of the new primary production for the gyre.

Besides $\mathrm{N}$ sources reported in Table 2, another important $\mathrm{N}$ source could come from the open ocean mesoscale activity. Poorly studied in the South Atlantic Ocean, Oschlies and Garçon (1998) estimated the role of eddy-induced nutrient supply in sustaining primary production in the North Atlantic subtropical gyre, and concluded that about $30-40 \%$ of new 


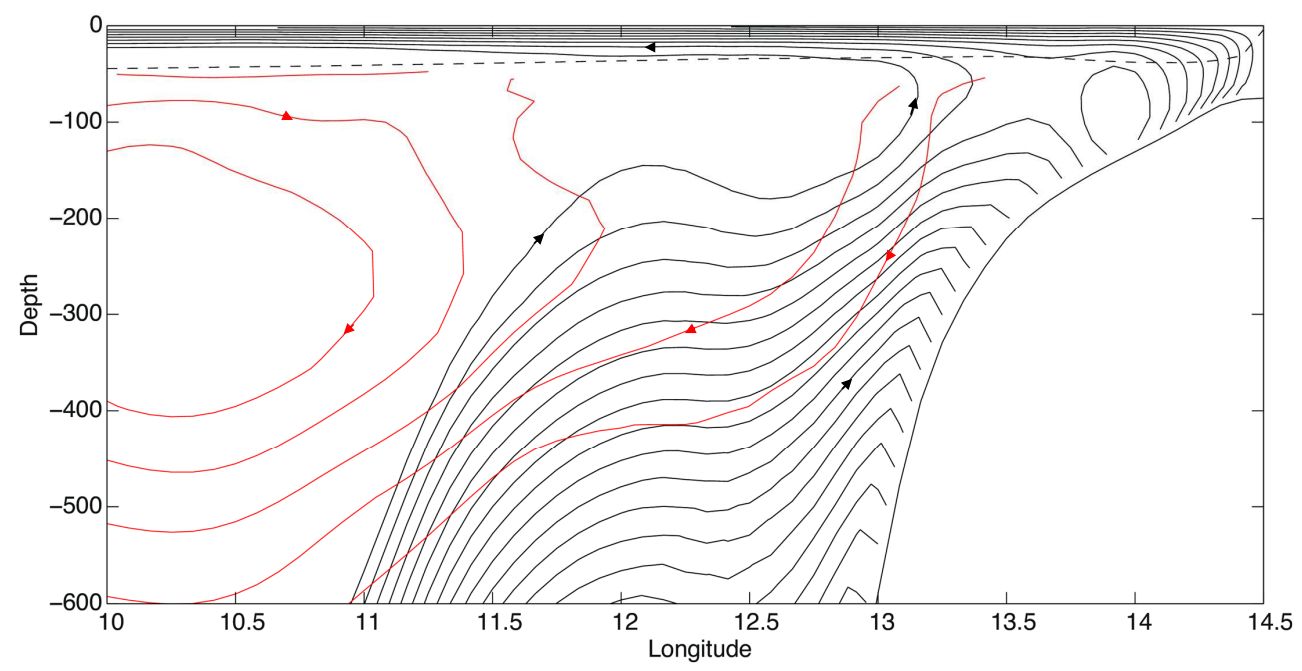

Fig. 6. Alongshore component of vector streamfunction $\left(\mathrm{m}^{2} \mathrm{~s}^{-1}\right)$ constructed from zonal velocities. In black: mean streamfunction constructed from the mean zonal velocity $(\bar{u})$; in red: bolus streamfunction associated with the zonal bolus velocity $\left(u^{*}\right)$, please see Colas et al. (2013) for details.. The dashed line represents the mean depth of mixed layer.

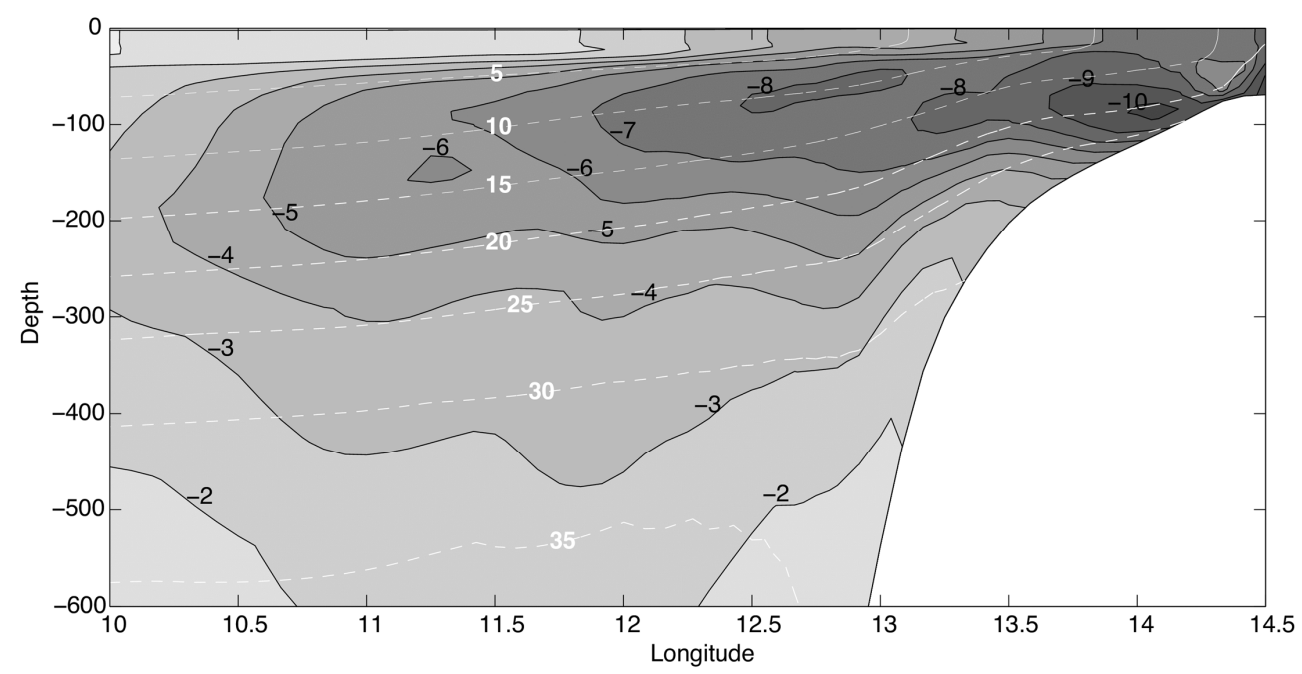

Fig. 7. Nitrate deficit $\left(\mathrm{mmol} \mathrm{N} \mathrm{m}^{-3}\right)$ between the eddy-resolving simulation and a non eddy-resolving simulation, featuring the role of eddies on vertical distribution of nutrients in the Benguela upwelling system. Dashed lines represent nitrate isocontours for the eddy-resolving simulation. The fields are averaged between $22^{\circ} \mathrm{S}$ and $24^{\circ} \mathrm{S}$.

production in the subtropics and mid-latitudes was due to mesoscale eddy activity. So, $\mathrm{N}$ source from the coastal upwelling and open ocean mesoscale activity could be the two major N sources sustaining primary production in the South Atlantic subtropical gyre. Obviously, an estimation of the mesoscale role as well as submesoscale impact in the South Atlantic Ocean is necessary to conclude. $\mathrm{N}_{2}$ biological fixation in the subtropical South Atlantic Ocean also appears to represent a significant $\mathrm{N}$ source for the subtropical gyre, following Ganachaud and Wunsch (2002) (Table 2). However, their estimation is higher by two orders of magnitude than the other $\mathrm{N}_{2}$ fixation estimation made in the South Atlantic gyre (Table 2). Large incertitude remains on the $\mathrm{N}$ sources for the South Atlantic subtropical gyre.

\subsection{Export production and $\mathrm{N}$ losses}

High primary production associated with EBUS produces important vertical nitrogen and carbon export fluxes (export production). For comparison with other studies, we took a C/N Redfield ratio of 106/16 (Redfield et al., 1963). At depth, this OM supply participates to the OMZ maintaining in which suboxic biogeochemical processes take place, associated with losses of fixed $\mathrm{N}$. 
Table 2. $\mathrm{N}$ source estimates $\left(\mathrm{mol} \mathrm{N} \mathrm{m}^{-2} \mathrm{yr}^{-1}\right)$ at regional and global scales.

\begin{tabular}{llll}
\hline $\begin{array}{l}\mathrm{N} \text { source } \\
\left(\mathrm{mol} \mathrm{N} \mathrm{m} \mathrm{yr}^{-1}\right)\end{array}$ & Area & Method & Reference \\
\hline $\mathrm{N}_{2}$ biological fixation & & \\
\hline $\begin{array}{l}0.0058 \pm 0.0025 \\
0.4 \pm 0.17\end{array}$ & $\begin{array}{l}\text { South Atlantic Gyre } \\
\text { Subtropical South } \\
\text { Atlantic }\end{array}$ & $\begin{array}{l}\text { AMT17 cruise } \\
\text { WOCE data + box model }\end{array}$ & $\begin{array}{l}\text { Moore et al. (2009) } \\
\text { Ganachaud and } \\
\text { Wunsch (2002) }\end{array}$ \\
\hline Atmospherical deposition & Global ocean & Duce et al. (2008) \\
\hline 0.013 & Global ocean & Galloway et al. (2004) \\
0.008 & South Atlantic & Galloway et al. (2004) \\
0.002 & South Atlantic Gyre & AMT10 cruise & Mahaffey et al. (2004) \\
\hline Meridional transport (Ekman flux): & & This study \\
\hline NO ${ }_{3}^{-}: 0.005$ & & & \\
DON: 0.015 & South Atlantic Gyre & model & \\
\hline Benguela upwelling system & & \\
\hline $0.1 \pm 0.04$ & & &
\end{tabular}

\subsubsection{Vertical sinking and total $\mathrm{N}$ export production}

In the surface layer, biological activity represents a net sink of DIN, and a net source of particulate and dissolved OM (Fig. 4), both fluxes being balanced in this equilibrated ecosystem. Nitrates sustain $81 \%$ of total primary production and ammonium $18 \%$, nitrite being mostly an intermediate in the oxidation of ammonium to nitrate. This high $f$ ratio $(0.8)$ for the Walvis Bay area is higher than the mean $f$ ratio of 0.3 for the northern Benguela sub-system (Monteiro, 2010), but closer to values of $0.5-1$ for the Californian and Peruvian systems (Monteiro, 2010). This high $f$ ratio comes from the dominant influence of local upwelling which supplies nitrates to the Walvis Bay area. Then high plankton biomass feeds the detritus pool by plankton mortality (57\%) and faecal pellets $(43 \%)$, and the ammonium and DON pools by excretion. DON is mostly decomposed in the surface layer while only $50 \%$ of detritus locally produced are decomposed in the surface area; the other part sinks along the water column by gravitation (Fig. 4). Vertical sinking of detritus and diatoms is estimated to $14.4 \pm 1.1 \times 10^{10} \mathrm{~mol} \mathrm{~N} \mathrm{yr}^{-1}$, with large detritus being the main contributor $(91 \%$ of the total vertical sinking).

Vertical sinking clearly sustains the total $\mathrm{N}$ export production (sum of vertical sinking and diffusion of DON and PON: $16.9 \pm 1.3 \times 10^{10} \mathrm{~mol} \mathrm{Nyr}^{-1}$ ) at $50 \mathrm{~m}$ depth on the Walvis Bay area (Fig. 4), and feeds the intermediate layer in OM to be decomposed. Monteiro (2010) estimated the total annual carbon export flux in the Benguela to $0.038{\mathrm{GtC} \mathrm{yr}^{-1}}^{-}$ using a box model, in the range of the different estimations reported in the Benguela $\left(0.02-0.09 \mathrm{Gt} \mathrm{C} \mathrm{yr}^{-1}\right.$; see Table 2.4.2 from Monteiro, 2010). Taking into account the con- sidered surfaces, the estimation of Monteiro (2010) for the Benguela system represents a lower bound; the Benguela is characterized by a carbon export flux range of 1.7$2.9 \mathrm{~mol} \mathrm{~N} \mathrm{~m}^{-2} \mathrm{yr}^{-1}$. The Northern Benguela is slightly more efficient in terms of export flux, with $1.83 \mathrm{~mol} \mathrm{~N} \mathrm{~m}^{-2} \mathrm{yr}^{-1}$. For the Walvis Bay area, the total $\mathrm{N}$ export production per square meter $\left(1.6 \pm 0.1 \mathrm{~mol} \mathrm{~N} \mathrm{~m}^{-2} \mathrm{yr}^{-1}\right)$ is slightly lower than the previous range. Our studied area extends from the coast to $10^{\circ} \mathrm{E}$, while Monteiro (2010) considers the Benguela system to be the $500 \mathrm{~m}$ depth contour. Taking the same limit as Monteiro (2010), $\mathrm{N}$ export production is estimated to $2.3 \pm 0.04 \mathrm{~mol} \mathrm{~N} \mathrm{~m}^{-2} \mathrm{yr}^{-1}$, in the range of estimations made in the Benguela system. This result is close to the upper bound, in agreement with the fact that Walvis Bay is a productive area.

\subsubsection{N losses}

Export production contributes to the oxygen sink in the intermediate layer as oxygen is consumed by OM decomposition and nitrification processes. Due to these local biogeochemical processes associated with physical remote forcing (Monteiro et al., 2006, 2008 and 2011; Hutchings et al., 2009; Gutknecht et al., 2013), low oxygen concentrations are frequently found in the subsurface waters off Namibia, mainly between 100 and $600 \mathrm{~m}$ depth. Under suboxic marine conditions $\left(\mathrm{O}_{2}<25 \mathrm{mmol} \mathrm{O}_{2} \mathrm{~m}^{-3}\right)$, a coupling between nitrifying, denitrifying and anammox bacteria occurs and produces losses of fixed $\mathrm{N}$.

In the Walvis Bay area studied here, estimated losses of fixed $\mathrm{N}$ due to denitrification and anammox processes in the water column $\left(0.04 \pm 0.025 \times 10^{10} \mathrm{~mol} \mathrm{~N} \mathrm{yr}^{-1}\right.$; 
Gutknecht et al., 2013) are clearly insufficient to affect the $\mathrm{N}$ offshore export $\left(8.5 \pm 3.9 \times 10^{10} \mathrm{~mol} \mathrm{~N} \mathrm{yr}^{-1}\right)$ as well as the export production $\left(16.9 \pm 1.3 \times 10^{10} \mathrm{~mol} \mathrm{~N} \mathrm{yr}^{-1}\right)$ of this productive area. For the whole Benguela system, Kuypers et al. (2005) estimated the $\mathrm{N}$ loss only due to anammox to be $1.4 \pm 1 \mathrm{Tg} \mathrm{Nyr}^{-1}$ (or $10 \pm 7.15 \times 10^{10} \mathrm{~mol} \mathrm{Nyr}^{-1}$ ), based on in situ experiments off Namibia. This loss of fixed $\mathrm{N}$ is on the same order as export production $\left(0.02-0.09 \mathrm{Gt} \mathrm{C} \mathrm{yr}^{-1}\right.$ or $25.2-113.2 \times 10^{10} \mathrm{~mol} \mathrm{~N} \mathrm{yr}^{-1}$ ) reported by Monteiro (2010) and $\mathrm{N}$ offshore export $\left(86.7 \pm 39.8 \times 10^{10} \mathrm{~mol} \mathrm{~N} \mathrm{yr}^{-1}\right.$; extrapolation from the Walvis Bay area's estimation). Our climatological simulation certainly represents a lower bound to the $\mathrm{N}$ loss estimation due to monthly averaged forcing, unable to simulate extreme events (Gutknecht et al., 2013). On the other hand, the extrapolation from Kuypers et al. (2005) certainly represents an upper limit as during the time of the cruise, Namibian shelf waters were particularly deoxygenated, far from the annual mean conditions of the Benguela system.

\section{4 $\quad \mathrm{N}_{2} \mathrm{O}$ emissions to the atmosphere}

Previous sections focused on lateral and vertical $\mathrm{N}$ transports. We are now interested in the nitrogen exchanges at the ocean-atmosphere interface as $\mathrm{N}_{2} \mathrm{O}$ fluxes. Remember that the $\mathrm{N}_{2} \mathrm{O}$ equation in the BioEBUS model is a parameterization based on nitrification and oxygen concentrations (Suntharalingam et al., 2000, 2012). Therefore, $\mathrm{N}_{2} \mathrm{O}$ does not interact with the other variables of the biogeochemical model.

At $10^{\circ} \mathrm{E}$, simulated $\mathrm{N}_{2} \mathrm{O}$ sea-air fluxes $\left(+0.18 \pm 0.02 \times 10^{-2} \mathrm{mmol} \mathrm{N}_{2} \mathrm{O} \mathrm{m}^{-2} \mathrm{~d}^{-1}\right.$; Table 3) are higher than those estimated over the South Atlantic subtropical gyre from in situ measurements made during AMT 12 (May-June 2003) and AMT 13 (September-October 2003) cruises (Table 3). Using Wanninkhof (1992) relationships, emissions were estimated to be $+0.13 \times 10^{-2}$ and $+0.04 \times 10^{-2} \mathrm{mmol} \mathrm{N}_{2} \mathrm{O} \mathrm{m}^{-2} \mathrm{~d}^{-1}$ in austral autumn and spring, respectively (Robinson et al., 2006; Forster et al., 2009). However, the track of both cruises was in the oligotrophic gyre $\left(10^{\circ} \mathrm{S}\right.$ to $30^{\circ} \mathrm{S}-25^{\circ} \mathrm{W}$; see tracks in Fig. 1 from Robinson et al., 2006), while even at the western boundary of the Namibian configuration $\left(5^{\circ} \mathrm{E}\right)$, conditions are not oligotrophic.

Simulated $\mathrm{N}_{2} \mathrm{O}$ fluxes at the ocean-atmosphere interface present a cross-shore gradient up to $+1.4 \pm 0.3 \times 10^{-2} \mathrm{mmol} \mathrm{N}_{2} \mathrm{O} \mathrm{m}^{-2} \mathrm{~d}^{-1}$ along the coast (Table 3). This gradient is difficult to validate as until 2009, there was no $\mathrm{N}_{2} \mathrm{O}$ in situ data in the BUS. In December 2009, the FRS Africana cruise in the framework of the GENUS project realized the first $\mathrm{N}_{2} \mathrm{O}$ in situ measurements along the Walvis Bay transect $\left(23^{\circ} \mathrm{S}\right)$. Ocean-atmosphere $\mathrm{N}_{2} \mathrm{O}$ fluxes were then estimated using mean values from three samples from each Niskin bottle. Some assumptions were made. First, concentrations measured at the first bottle (between 4 and $18 \mathrm{~m}$ depth) are assumed to be representative of surface conditions. Secondly, the same formulation as the one used in BioEBUS (gas transfer velocity and Schmidt number from Wanninkhof, 1992) is used to estimate oceanatmosphere $\mathrm{N}_{2} \mathrm{O}$ fluxes. Thirdly, we used the same wind speeds (for December) as those used to force the coupled model, deduced from the QuikSCAT monthly climatology. The simulated fluxes present a shoreward increase similar to the three estimations made at $13.2^{\circ} \mathrm{E}, 13.7^{\circ} \mathrm{E}$ and $14.1^{\circ} \mathrm{E}$ (Table 3) with, however, lower estimations on $8 \mathrm{yr}$ average, but more comparable estimations for the maximum values (see values in brackets). Indeed, the upwelled waters were particularly $\mathrm{O}_{2}$-depleted and $\mathrm{N}_{2} \mathrm{O}$-enriched during the time of the cruise (see Fig. 9 from Gutknecht et al., 2013). Close to the coast, ocean-atmosphere $\mathrm{N}_{2} \mathrm{O}$ flux from in situ observations could not be estimated as $\mathrm{N}_{2} \mathrm{O}$ concentrations measured in the water column at $14.3^{\circ} \mathrm{E}$ had too important standard deviations. This first comparison gives promising results. Moreover, in view of reported $\mathrm{N}_{2} \mathrm{O}$ emissions off Chile, Mauritania and California (Table 3), mean coastal $\mathrm{N}_{2} \mathrm{O}$ emissions simulated off Walvis Bay as well as maximum values are in the range of $\mathrm{N}_{2} \mathrm{O}$ emissions estimated in the EBUS. It is, however, obvious that more in situ data are needed to really capture the spatial distribution and variability of $\mathrm{N}_{2} \mathrm{O}$ emissions to the atmosphere in the Namibian upwelling system.

Nevison et al. (2004) quantified the $\mathrm{N}_{2} \mathrm{O}$ emissions from the world's major eastern boundary regions using an upwelling model and in situ data, and suggested their release contributes to about $5 \%$ of the total ocean sources. In their study, coastal upwelling areas do not extend more than 100 $\mathrm{km}$ offshore. For comparison, we use the same offshore bound and named this region "the Walvis Bay coastal area" in the following. Estimated $\mathrm{N}_{2} \mathrm{O}$ outgassing for the Walvis Bay coastal area contributes to $0.8 \%$ of the emissions of the EBUS (+200 $\pm 140 \mathrm{Gg} \mathrm{N} \mathrm{yr}^{-1}$; Table 4). This contribution varies between $0.5 \%$ and $2.7 \%$ due to considerable uncertainty in the estimation from Nevison et al. (2004). In terms of emissions per unit area, the Walvis Bay coastal area emits $0.7 \pm 0.01 \times 10^{-2} \mathrm{mmol} \mathrm{N}_{2} \mathrm{O} \mathrm{m}^{-2} \mathrm{~d}^{-1}$, in the range of estimations made for all EBUS but slightly lower than estimation for the whole South-West Africa area (Table 4). Currently, with the qualities and defaults of the simulated OMZ off Namibia, $\mathrm{N}_{2} \mathrm{O}$ production associated with the $\mathrm{OMZ}$ of the Walvis Bay area is mostly advected southward by the poleward undercurrent (Gutknecht et al., 2013) and certainly outgases at Lüderitz cell. This explains our current estimation as compared to the South-West Africa area (Table 4) and the recent measurements made off Walvis Bay during the FRS Africana cruise (Table 3). However, the Walvis Bay coastal area certainly contributes more efficiently than our current estimation. Observed OMZ is more developed over the continental shelf than the simulated one (Gutknecht et al., 2013). Then, high $\mathrm{N}_{2} \mathrm{O}$ concentrations can directly be upwelled and outgased off the Walvis Bay area. 
Table 3. $\mathrm{N}_{2} \mathrm{O}$ emissions to the atmosphere $\left(10^{-2} \mathrm{mmol} \mathrm{N}_{2} \mathrm{O} \mathrm{m}^{-2} \mathrm{~d}^{-1}\right)$ estimated in EBUS using the atmospheric convention (positive flux means an outgassing of $\mathrm{N}_{2} \mathrm{O}$ from the ocean to the atmosphere).

\begin{tabular}{|c|c|c|c|}
\hline $\begin{array}{l}\text { Upwelling } \\
\text { System }\end{array}$ & Method & $\begin{array}{l}\mathrm{N}_{2} \mathrm{O} \text { emissions } \\
\left.10^{-2} \mathrm{mmol} \mathrm{N}_{2} \mathrm{O} \mathrm{m}^{-2} \mathrm{~d}^{-1}\right)\end{array}$ & Reference \\
\hline $\begin{array}{l}\text { Walvis Bay } \\
\text { area } \\
\left(22-24^{\circ} \mathrm{S}\right)\end{array}$ & $\begin{array}{l}\text { model } \\
8 \text { yr mean } \pm \text { std }(\max )\end{array}$ & $\begin{array}{l}\text { at } 10^{\circ} \mathrm{E}:+0.18 \pm 0.02 \\
\text { to the coast: }+1.4 \pm 0.3(+5.1) \\
13.2^{\circ} \mathrm{E}:+0.4 \pm 0.01(+1.1) \\
13.7^{\circ} \mathrm{E}:+0.5 \pm 0.02(+1.4) \\
14.1^{\circ} \mathrm{E}:+0.8 \pm 0.08(+4.3)\end{array}$ & This study \\
\hline $\begin{array}{l}\text { Walvis Bay } \\
\left(23^{\circ} \mathrm{S}\right)\end{array}$ & $\begin{array}{l}1 \text { section } \\
\text { ( } 3 \text { estimations) }\end{array}$ & $\begin{array}{l}13.2^{\circ} \mathrm{E}:+2.4 \pm 0.7 \\
13.7^{\circ} \mathrm{E}:+3 \pm 0.4 \\
14.1^{\circ} \mathrm{E}:+3.6 \pm 0.6\end{array}$ & $\begin{array}{l}\text { FRS Africana data } \\
\text { (December 2009) }\end{array}$ \\
\hline Chile & $\begin{array}{l}4 \text { cruises } \\
1 \text { station }(67 \mathrm{~m} \text { depth })\end{array}$ & $\begin{array}{l}+6 \text { (annual mean }) \\
-0.18 \text { to }+33 \\
+4.5 \text { (annual mean })\end{array}$ & Paulmier et al. (2008) \\
\hline Mauritania & $\begin{array}{l}\text { using simple upwelling } \\
\text { model, in situ } \mathrm{N}_{2} \mathrm{O} \\
\text { measurements and } \\
\text { QuikSCAT product }\end{array}$ & $\begin{array}{l}+0.26 \text { (mean) } \\
\text { up to }+17 \text { (North) } \\
\text { up to }+9 \text { (South) }\end{array}$ & Wittke et al. (2010) \\
\hline Mauritania & 3 cruises & -0.17 to 4.3 & Kock et al. (2012) \\
\hline California & $\begin{array}{l}\text { using satellite } \\
\text { ocean observations, and } \\
\text { and empirical formulation }\end{array}$ & +11 (upwelling events) & Lueker et al. (2003) \\
\hline
\end{tabular}

\section{Conclusions}

The coupled physical/biogeochemical model (ROMS/BioEBUS), developed and validated for examination of the Namibian upwelling system, was used to study the following nitrogen transfers in the Walvis Bay area (between $22^{\circ} \mathrm{S}$ and $24^{\circ} \mathrm{S}$ ): $\mathrm{N}$ offshore export, export production, and the subsequent $\mathrm{N}$ losses and nitrogen $\left(\mathrm{N}_{2} \mathrm{O}\right)$ exchange at the ocean-atmosphere interface.

The characteristics of the Walvis Bay area are typical of EBUS, with local wind-driven upwelling supporting high primary production and surface offshore Ekman transport. The $\mathrm{N}$ budget in this bay is also controlled by the meridional advection. Indeed, the Benguela current enriched in nitrates represents a nitrogen source in the surface layer and the undercurrent below this surface layer, a nitrogen sink. Eddy advective transport acts against the wind-driven circulation, resulting in a nitrate deficit and a primary production decrease of about $17 \%$. This effect should be accounted for in global estimations of primary production. In the mixed layer, mesoscale eddies (and frontal processes) provide a more complicated pattern. However, at $10^{\circ} \mathrm{E}$, they contribute $20 \%$ of the total $\mathrm{N}$ offshore export, confirming the significant role of mesoscale activity in the cross-shore exports. The $\mathrm{N}$ offshore export cannot therefore be reduced to Ekman and geostrophic transports. Nitrates and plankton (especially diatoms, ciliates and copepods) equally contribute to the $\mathrm{N}$
Table 4. $\mathrm{N}_{2} \mathrm{O}$ emissions to the atmosphere $\left(\mathrm{Gg} \mathrm{Nyr}^{-1}\right.$ and $\mathrm{g} \mathrm{N} \mathrm{m}^{-2} \mathrm{yr}^{-1}$ ) estimated in this study ( $8 \mathrm{yr}$ mean \pm standard deviation) and compared with estimations from Nevison et al. (2004).

\begin{tabular}{|c|c|c|c|}
\hline & $\begin{array}{l}\text { surfaces } \\
\left(\mathrm{km}^{2}\right)\end{array}$ & $\begin{array}{l}\mathrm{N}_{2} \mathrm{O} \text { emissions } \\
\left(\mathrm{Gg} \mathrm{N} \mathrm{yr}^{-1}\right)\end{array}$ & $\begin{array}{l}\mathrm{N}_{2} \mathrm{O} \text { emissions } \\
\left(10^{-2} \mathrm{mmol} \mathrm{N}_{2} \mathrm{O}\right) \\
\mathrm{m}^{-2} \mathrm{~d}^{-1}\end{array}$ \\
\hline $\begin{array}{l}\text { Walvis Bay coastal } \\
\text { area (This study) }\end{array}$ & $2.3510^{4}$ & $+1.6 \pm 0.02$ & $+0.7 \pm 0.01$ \\
\hline $\begin{array}{l}\text { all EBUS } \\
\text { (Nevison et al., 2004) }\end{array}$ & $1.7510^{6}$ & $+200 \pm 140$ & +0.6 to +1.6 \\
\hline $\begin{array}{l}\text { South-West Africa } \\
\text { (Nevison et al., 2004) }\end{array}$ & $1.910^{5}$ & +16 & +0.8 \\
\hline
\end{tabular}

offshore export while, unexpectedly, DON only plays a secondary role. The BUS is shown to be a significant $\mathrm{N}$ source for the eastern part of the South Atlantic subtropical gyre, potentially contributing to $28-42 \%$ of the new primary production estimated for the gyre.

The high export production sustained by large detritus sinking, and associated with remote forcing, contributes to the maintenance of an oxygen minimum zone off Namibia in which coupled nitrification, denitrification and anammox processes lead to $\mathrm{N}$ losses and $\mathrm{N}_{2} \mathrm{O}$ production. However, $\mathrm{N}$ losses and $\mathrm{N}_{2} \mathrm{O}$ emissions simulated in the Walvis Bay area have a negligible impact on the main $\mathrm{N}$ exports of the region. 
Estimated $\mathrm{N}_{2} \mathrm{O}$ outgassing (mean value: $0.7 \pm 0.01 \times 10^{-2} \mathrm{mmol} \mathrm{N}_{2} \mathrm{O} \mathrm{m}^{-2} \mathrm{~d}^{-1}, \quad$ coastal maximum value: $+1.4 \pm 0.3 \times 10^{-2} \mathrm{mmol} \mathrm{N}_{2} \mathrm{O} \mathrm{m}^{-2} \mathrm{~d}^{-1}$ ) has the same order of magnitude as the first fluxes estimated off Walvis Bay during the FRS Africana cruise in December 2009. The coastal domain of the Walvis Bay area does not represent a significant area of $\mathrm{N}_{2} \mathrm{O}$ emissions compared to the South-West Africa region, as $\mathrm{N}_{2} \mathrm{O}$ locally produced is mostly advected southward by the poleward undercurrent.

In future work, the $\mathrm{N}$ fluxes discussed in this paper will be estimated for the whole BUS using the SAfE configuration and interannual forcings. To better depict very low $\mathrm{O}_{2}$ concentrations on the continental shelf waters and improve $\mathrm{N}$ loss and $\mathrm{N}_{2} \mathrm{O}$ outgassing estimations, future model developments will be necessary. A sediment module will be added to the BioEBUS model. Parameterization of biogeochemical processes associated with low $\mathrm{O}_{2}$ waters will also be improved. To estimate the response of the global ocean to present and future climatic changes, it is crucial to better understand the complex processes involved in OMZs and their representation in coupled models.

Acknowledgements. We would like to thank the CNES and Midi-Pyrénées Region for the financial Ph.D. support and the Paul Sabatier University for the ATER support attributed to E. Gutknecht, and the CNES support (TOSCA CNES program) to I. Dadou and V. Garçon. A COST Action 735 grant to E. Gutknecht is also acknowledged. We thank the European MEECE project (EU grant agreement number 212085) for providing funding to develop this study. This work was performed using HPC resources from CALMIP (grant 2011-2012-[P1044]). We are very grateful to Nick Hall for English corrections and the three anonymous reviewers as well as the editor for their very helpful comments.

Edited by: C. P. Slomp

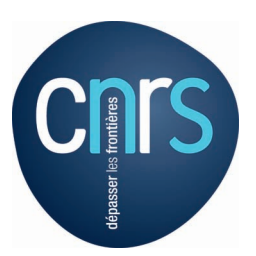

The publication of this article is financed by CNRS-INSU.

\section{References}

Aiken, J.: Atlantic Meridional Transect, AMT 6 cruise report, 14 May to 16 June 1998, 1998.

Aiken, J. and Bale, A. J.: An introduction to the Atlantic Meridional Transect (AMT) Programme, Prog. Oceanogr., 45, 251256, doi:10.1016/S0079-6611(00)00004-5, 2000.

Aiken, J., Rees, N., Hooker, S., Holligan, P., Bale, A., Robins, D., Moore, G., Harris, R., and Pilgrim, D.: The Atlantic Meridional Transect: overview and synthesis of data, Prog. Oceanogr., 45, 257-312, doi:10.1016/S0079-6611(00)00005-7, 2000.
Bange, H.: New Directions: The importance of oceanic nitrous oxide emissions, Atmos. Environ., 40, 198-199, doi:10.1016/j.atmosenv.2005.09.030, 2006.

Bange, H.: Gaseous nitrogen compounds $\left(\mathrm{NO}, \mathrm{N}_{2} \mathrm{O}, \mathrm{N}_{2}, \mathrm{NH}_{3}\right)$ in the ocean, in: Nitrogen in the Marine Environment, 51-94, edited by: Capone, D. G., Bronk, D. A., Mulholland, M. R., and Carpenter, E. J., Amsterdam, 2008.

Barlow, R., Lamont, T., Mitchell-Innes, B., Lucas, M., and Thomalla, S.: Primary production in the Benguela ecosystem, 1999-2002, Afr. J. Mar. Sci., 31, 97-101, doi:10.2989/AJMS.2009.31.1.9.780, 2009.

Barnier, B., Siefridt, L., and Marchesiello, P.: Thermal forcing for a global ocean circulation model using a three-year climatology of ECMWF analyses, J. Mar. Syst., 6, 363-380, doi:10.1016/09247963(94)00034-9, 1995.

Boebel, O., Rossby, T., Lutjeharms, J., Zenk, W., and Barron, C.: Path and variability of the Agulhas Return Current, DeepSea Res. Pt II, 50, 35-56, doi:10.1016/S0967-0645(02)00377-6, 2003.

Brown, P. C., Painting, S. J., and Cochrane, K. L.: Estimates of phytoplankton and bacterial biomass and production in the northern and southern Benguela ecosystems, S. Afr. J. Sci., 11, 537-564, 1991.

Capet, X., Colas F., Penven P., Marchesiello P. and McWilliams J. C., Eddies in Eastern Boundary Subtropical Upwelling Systems, in: Geophysical Monograph Series, vol. 177, Ocean Modeling in an Eddying Regime, edited by: Hecht, M. W. and Hasumi, H. H., AGU, Washington DC, 350 pp., 2008.

Carr, M. E.: Estimation of potential productivity in Eastern Boundary Currents using remote sensing, Deep-Sea Res. Pt II, 49, 59 $80,2002$.

Carr, M. and Kearns, E. J.: Production regimes in four Eastern Boundary Current systems, Deep-Sea Res. Pt. II, 50, 3199-3221, doi:10.1016/j.dsr2.2003.07.015, 2003.

CARS: CSIRO Atlas of Regional Seas, http://www.marine.csiro.au/ $\sim$ dunn/cars2006, 03/30/2011, 2006.

CARS: CSIRO Atlas of Regional Seas, http://www.marine.csiro.au/ $\sim$ dunn/cars2009, 03/30/2011, 2009.

Casey, K. S. and Cornillon, P.: A comparison of satellite and in situ-based sea surface temperature climatologies, J. Climate, 12, 1848-1863, 1999.

Charria, G., Dadou, I., Cipollini, P., Drévillon, M., De Mey, P., and Garçon, V.: Understanding the influence of Rossby waves on surface chlorophyll-a concentrations in the North Atlantic Ocean, J. Mar. Res., 64, 43-71, doi:10.1357/002224006776412340, 2006.

Chavez, F. P. and Messié, M.: A comparison of Eastern Boundary Upwelling Ecosystems, Prog. Oceanogr., 83, 80-96, doi:10.1016/j.pocean.2009.07.032, 2009.

Chavez, F. P. and Toggweiler, K.: Upwelling in the Ocean: Modern Processes and Ancient Records, John Wiley \& Sons, 1995.

Codispoti, L. A.: Interesting Times for Marine $\mathrm{N}_{2} \mathrm{O}$, Science, 327, 1339-1340, doi:10.1126/science.1184945, 2010.

Codispoti, L. A., Brandes, J. A., Christensen, J. P., Devol, A. H., Naqvi, S. W. A., Paerl, H. W., and Yoshinari, T.: The oceanic fixed nitrogen and nitrous oxide budgets: Moving targets as we enter the anthropocene?, Sci. Mar., 65, 85-105, doi:10.3989/scimar.2001.65s285, 2001.

Colas, F., Capet , X., McWilliams, J. C., and Li, Z.: Mesoscale eddy buoyancy flux and eddy-induced circulation in Eastern Boundary 
Currents, J. Phys. Oceanogr., in press, doi:10.1175/JPO-D-110241.1, 2013.

Conkright, M. E., O’Brien, T. D., Stephens, C., Locarnini, R. A., Garcia, H. E., Boyer, T. P., and Antonov, J. I.: World Ocean Atlas 2001, Volume 6: Chlorophyll, edited by: Levitus, S., NOAA Atlas NESDIS 52, US Government Printing Office, Washington DC, 2002.

Cornejo, M., Farías, L., and Paulmier, A.: Temporal variability in $\mathrm{N}_{2} \mathrm{O}$ water content and its air-sea exchange in an upwelling area off central Chile $\left(36^{\circ} \mathrm{S}\right)$, Mar. Chem., 101, 85-94, doi:10.1016/j.marchem.2006.01.004, 2006.

Da Silva, A. M., Young, C. C. and Levitus, S.: Atlas of Surface Marine Data 1994. Vol. 1: Algorithms and Procedures, NOAA Atlas NESDIS 6, Department of Commerce, Washington, DC, USA, 1994.

Debreu, L., Marchesiello, P., Penven, P. and Cambon, G.: Two-way nesting in split-explicit ocean models: algorithms, implementation and validation, Ocean Model., doi:10.1016/j.ocemod.2012.03.003, 2012.

Denman, K. L., Brasseur, G., Chidthaisong, A., Ciais, P., Cox, P. M., Dickinson, R. E., Hauglustaine, D., Heinze, C., Holland, E., Jacob, D., Lohmann, U., Ramachandran, S., da Silva Dias, P. L., Wofsy, S. C., and Zhang, X.: Couplings Between Changes in the Climate System and Biogeochemistry, in Climate Change 2007: The Physical Science Basis. Contribution of Working Group I to the Fourth Assessment Report of the Intergovernmental Panel on Climate Change, edited by: Solomon, S., Qin, D., Manning, M., Chen, Z., Marquis, M., Averyt, K. B., Tignor, M., and Miller H. L., Cambridge University Press, Cambridge, United Kingdom and New York, NY, USA, 2007.

Duce, R. A., LaRoche, J., Altieri, K., Arrigo, K. R., Baker, A. R., Capone, D. G., Cornell, S. Dentener, F., Galloway, J., Ganeshram, R. S., Geider, R. J., Jickells, T., Kuypers, M. M., Langlois, R., Liss, P. S., Liu, S. M., Middelburg, J. J., Moore, C. M., Nickovic, S., Oschlies, A., Pedersen, T., Prospero, J., Schlitzer, R., Seitzinger, S., Sorensen, L. L., Uematsu, M., Ulloa, O., Voss, M., Ward, B., and Zamora, L.: Impacts of Atmospheric Anthropogenic Nitrogen on the Open Ocean, Science, 320, 893 897, doi:10.1126/science.1150369, 2008.

Ekau, W., Auel, H., Pörtner, H.-O., and Gilbert, D.: Impacts of hypoxia on the structure and processes in pelagic communities (zooplankton, macro-invertebrates and fish), Biogeosciences, 7, 1669-1699, doi:10.5194/bg-7-1669-2010, 2010.

Farias, L., Paulmier, A., and Gallegos, M.: Nitrous oxide and Nnutrient cycling in the oxygen minimum zone off northern Chile, Deep-Sea Res. Pt I, 54, 164-180, doi:10.1016/j.dsr.2006.11.003, 2007.

Forster, G., Upstill-Goddard, R. C., Gist, N., Robinson, C., Uher, G., and Woodward, E. M. S.: Nitrous oxide and methane in the Atlantic Ocean between $50^{\circ} \mathrm{N}$ and $52^{\circ} \mathrm{S}$ : Latitudinal distribution and sea-to-air flux, Deep-Sea Res. Pt. II, 56, 964-976, doi:10.1016/j.dsr2.2008.12.002, 2009.

Fréon, P., Barange, M., and Arístegui, J.: Eastern Boundary Upwelling Ecosystems: Integrative and comparative approaches, Prog. Oceanogr., 83, 1-14, doi:10.1016/j.pocean.2009.08.001, 2009.

Galloway, J. N., Dentener, F. J., Capone, D. G., Boyer, E. W., Howarth, R. W., Seitzinger, S. P., Asner, G. P., Cleveland, C. C., Green, P. A., Holland, E. A., Karl, D. M., Michael, A. F., Porter,
J. H., Townsend, A. R., and Vorosmarty, C. J.: Nitrogen cycles: past, present, and future, Biogeochemistry, 70, 153-226, 2004.

Ganachaud, A. and Wunsch, C.: Oceanic nutrient and oxygen transports and bounds on export production during the World Ocean Circulation Experiment, Global Biogeochem. Cy., 16, 1057, doi:10.1029/2000GB001333, 2002.

Gilbert, D., Rabalais, N. N., Díaz, R. J., and Zhang, J.: Evidence for greater oxygen decline rates in the coastal ocean than in the open ocean, Biogeosciences, 7, 2283-2296, doi:10.5194/bg-72283-2010, 2010.

Gregg, W. W., Conkright, M. E., Ginoux, P., O'Reilly, J. E., and Casey, N. W.: Ocean primary production and climate: Global decadal changes, Geophys. Res. Lett., 30, 1809, doi:10.1029/2003GL016889, 2003.

Gruber, N. and Galloway, J.: An Earth-system perspective of the global nitrogen cycle, Nature, 451, 293-296, doi:10.1038/nature06592, 2008.

Gruber, N., Lachkar, Z., Frenzel, H., Marchesiello, P., Münnich, M., McWilliams, J. C., Nagai, T., and Plattner, G.-K.: Eddy-induced reduction of biological production in eastern boundary upwelling systems, Nat. Geosci., 4, 787-792, doi:10.1038/ngeo1273, 2011.

Gutknecht, E., Dadou, I., Charria, G., Cipollini, P., and Garçon, V.: Spatial and temporal variability of the remotely sensed chlorophyll-a signal associated with Rossby waves in the South Atlantic Ocean, J. Geophys. Res., 115, C05004, doi:10.1029/2009JC005291, 2010.

Gutknecht, E., Dadou, I., Le Vu, B., Cambon, G., Sudre, J., Garçon, V., Machu, E., Rixen, T., Kock, A., Flohr, A., Paulmier, A., and Lavik, G.: Coupled physical/biogeochemical modeling including $\mathrm{O}_{2}$-dependent processes in the Eastern Boundary Upwelling Systems: application in the Benguela, Biogeosciences, 10, 35593591, doi:10.5194/bg-10-3559-2013, 2013.

Huret, M., Dadou, I., Dumas, F., Lazure, P., and Garcon, V.: Coupling physical and biogeochemical processes in the Rio de la Plata plume, Cont. Shelf Res., 25, 629-653, doi:10.1016/j.csr.2004.10.003, 2005.

Hutchings, L., van der Lingen, C. D., Shannon, L. J., Crawford, R. J. M., Verheye, H. M. S., Bartholomae, C. H., van der Plas, A. K., Louw, D., Kreiner, A., Ostrowski, M., Fidel, Q., Barlow, R. G., Lamont, T., Coetzee, J., Shillington, F., Veitch, J., Currie, J. C., and Monteiro, P. M. S.: The Benguela Current: An ecosystem of four components, Prog. Oceanogr., 83, 15-32, doi:10.1016/j.pocean.2009.07.046, 2009.

Jain, A. K., Briegleb, B. P., Minschwaner, K., and Wuebbles, D. J.: Radiative forcings and global warming potentials of 39 greenhouse gases, J. Geophys. Res., 105, 20773-20790, 2000.

Keeling, R. F., Körtzinger, A., and Gruber, N.: Ocean deoxygenation in a warming world, Annu. Rev. Mar. Sci., 2, 199-229, doi:10.1146/annurev.marine.010908.163855, 2010.

Kock, A., Schafstall, J., Dengler, M., Brandt, P., and Bange, H. W.: Sea-to-air and diapycnal nitrous oxide fluxes in the eastern tropical North Atlantic Ocean, Biogeosciences, 9, 957-964, doi:10.5194/bg-9-957-2012, 2012.

Koné, V., Machu, E., Penven, P., Andersen, V., Garcon, V., Freon, P., and Demarcq, H.: Modeling the primary and secondary productions of the southern Benguela upwelling system: A comparative study through two biogeochemical models, Global Biogeochem. Cy., 19, doi:10.1029/2004GB002427, 2005. 
Kreiner, A. and Ayon, P.: Zooplankton dynamics from 1994 to 2006 in the upwelling systems off Peru and northern Namibia, Eastern boundary upwelling ecosystems, Las Palmas, Gran Canaria, Spain, 2-6 June 2008, P08_OP05, 2008.

Kuypers, M. M. M., Lavik, G., Woebken, D., Schmid, M., Fuchs, B. M., Amann, R., Jørgensen, B. B., and Jetten, M. S. M.: Massive nitrogen loss from the Benguela upwelling system through anaerobic ammonium oxidation, P. Natl. Acad. Sci. USA, 102, 6478-6483, doi:10.1073/pnas.0502088102, 2005.

Large, W. G., McWilliams, J. C., and Doney, S. C.: Oceanic vertical mixing: A review and a model with a nonlocal boundary layer parameterization, Rev. Geophys., 32, 363-403, doi:199410.1029/94RG01872, 1994.

Lavik, G., Stuhrmann, T., Bruchert, V., Van der Plas, A., Mohrholz, V., Lam, P., Muszmann, M., Fuchs, B. M., Amann, R., Lass, U., and Kuypers, M. M. M.: Detoxification of sulphidic African shelf waters by blooming chemolithotrophs, Nature, 457, 581584, doi:10.1038/nature07588, 2008.

Longhurst, A.: Ecological Geography of the Sea, Academic Press, 398 pp., 1998.

Lueker, T. J., Walker, S. J., Vollmer, M. K., Keeling, R. F., Nevison, C. D., Weiss, R. F. and Garcia, H. E.: Coastal upwelling air-sea fluxes revealed in atmospheric observations of $\mathrm{O}_{2} / \mathrm{N}_{2}, \mathrm{CO}_{2}$ and $\mathrm{N}_{2} \mathrm{O}$, Geophys. Res. Lett., 30, 1292, doi:10.1029/2002GL016615, 2003.

Lutjeharms, J. R. E., Boebel, O., and Rossby, H. T.: Agulhas cyclones, Deep-Sea Res. Pt. II, 50, 13-34, doi:10.1016/S09670645(02)00378-8, 2003.

Mahaffey, C., Williams, R. G., Wolff, G. A., and Anderson, W. T.: Physical supply of nitrogen to phytoplankton in the Atlantic Ocean, Global Biogeochem. Cy., 18, GB1034, doi:10.1029/2003GB002129, 2004.

Marchesiello, P., McWilliams, J. C., and Shchepetkin, A.: Open boundary conditions for long-term integration of regional oceanic models, Ocean Model., 3, 1-20, doi:10.1016/S14635003(00)00013-5, 2001.

Marchesiello, P., McWilliams, J. C., and Shchepetkin, A.: Equilibrium structure and dynamics of the California Current System, J. Phys. Oceanogr., 33, 753-783, 2003.

McClain, C. R., Cleave, M. L., Feldman, G. C., Gregg, W. W., Hooker, S. B., and Kuring, N.: Science Quality SeaWiFS Data for Global Biosphere Research, NASA/Goddard Space Flight Center, Sea Technol., 39, 10-16, 1998.

Mohrholz, V., Bartholomae, C. H., van der Plas, A. K., and Lass, H. U.: The seasonal variability of the northern Benguela undercurrent and its relation to the oxygen budget on the shelf, Cont. Shelf Res., 28, 424-441, doi:10.1016/j.csr.2007.10.001, 2008.

Mohrholz, V., Heene, T., Tsanwani, M., Morris, T., and Müller, A.: 1- Working group "Hydrography", in Geochemistry and Ecology of the Namibian Upwelling System (GENUS Project) and St Helena Bay Monitoring Line (SHBML), cruise report, FRS Africana, 1-17 December 2009, 2009.

Monteiro, P. M. S.: The Benguela Current System, in Chap. 2: Eastern Boundary Current Systems, in: Carbon and Nutrient Fluxes in Continental Margins: A Global Synthesis, edited by: Liu, K.-K. Atkinson, L., Quiñones, R., and Talaue-MacManus, L., Berlin, 65-78, 2010.

Monteiro, P. M. S., van der Plas, A., Mohrholz, V., Mabille, E., Pascall, A., and Joubert, W.: Variability of natural hy- poxia and methane in a coastal upwelling system: Oceanic physics or shelf biology?, Geophys. Res. Lett., 33, L16614, doi:10.1029/2006GL026234, 2006.

Monteiro, P. M. S., van der Plas, A. K., Mélice, J., and Florenchie, P.: Interannual hypoxia variability in a coastal upwelling system: Ocean-shelf exchange, climate and ecosystem-state implications, Deep-Sea Res. Pt. I, 55, 435-450, doi:10.1016/j.dsr.2007.12.010, 2008.

Monteiro, P. M. S., Dewitte, B., Scranton, M. I., Paulmier, A., and Van der Plas, A.: The Role of Open Ocean Boundary Forcing on Seasonal to Decadal Scale Variability and Long-Term Change of Natural Shelf Hypoxia, Environ. Res. Lett., 6, 025002 doi:10.1088/1748-9326/6/2/025002, 2011.

Moore, C. M., Mills, M. M., Achterberg, E. P., Geider, R. J., LaRoche, J., Lucas, M. I., McDonagh, E. L., Pan, X., Poulton, A. J., Rijkenberg, M. J. A., Suggett, D. J., Ussher, S. J., and Woodward, E. M. S.: Large-scale distribution of Atlantic nitrogen fixation controlled by iron availability, Nat. Geosci., 2, 867-871, doi:10.1038/NGEO667, 2009.

Naqvi, S. W. A., Bange, H. W., Farías, L., Monteiro, P. M. S., Scranton, M. I., and Zhang, J.: Marine hypoxia/anoxia as a source of $\mathrm{CH}_{4}$ and $\mathrm{N}_{2} \mathrm{O}$, Biogeosciences, 7, 2159-2190, doi:10.5194/bg7-2159-2010, 2010.

Nevison, C., Butler, J. H., and Elkins, J. W.: Global distribution of $\mathrm{N}_{2} \mathrm{O}$ and the Delta $\mathrm{N}_{2} \mathrm{O}$-AOU yield in the subsurface ocean, Global Biogeochem. Cy., 17, 1119, doi:10.1029/2003GB002068, 2003.

Nevison, C. D., Lueker, T. J., and Weiss, R. F.: Quantifying the nitrous oxide source from coastal upwelling, Global Biogeochem. Cy., 18, GB1018, doi:10.1029/2003GB002110, 2004.

O'Reilly, J. E., Maritorena, S., Siegel, D., O 'Brien, M., Toole, D., Greg Mitchell, B., Kahru, M., Chavez, F., Strutton, P., Cota, G., Hooker, S., McClain, C., Carder, K., Muller-Karger, F., Harding, L., Magnuson, A., Phinney, D., Moore, G., Aiken, J., Arrigo, K., Letelier, R., and Culver, M.: Ocean color chlorophyll-a algorithms for SeaWiFS, OC2, and OC4: Version 4, in: O'Reilly, J.E., and 24 coauthors: SeaWiFS Postlaunch Calibration and Validation Analyses, Part 3. NASA Tech. Memo. 2000-206892, Vol. 11, edited by: Hooker, S. B. and Firestone, E. R., NASA Goddard Space Flight Center, Greenbelt, Maryland, 9-23, 2000.

Oschlies, A. and Garcon, V.: Eddy-induced enhancement of primary production in a model of the North Atlantic Ocean, Nature, 394, 266-269, 1998.

Paulmier, A. and Ruiz-Pino, D.: Oxygen minimum zones (OMZs) in the modern ocean, Prog. Oceanogr., 80, 113-128, doi:10.1016/j.pocean.2008.08.001, 2009.

Paulmier, A., Ruiz-Pino, D., and Garcon, V.: The oxygen minimum zone (OMZ) off Chile as intense source of $\mathrm{CO}_{2}$ and $\mathrm{N}_{2} \mathrm{O}$, Cont. Shelf Res., 28, 2746-2756, doi:10.1016/j.csr.2008.09.012, 2008.

Pelegrí, J. L., Marrero-Díaz, A., and Ratsimandresy, A. W.: Nutrient irrigation of the North Atlantic, Prog. Oceanogr., 70, 366-406, doi:10.1016/j.pocean.2006.03.018, 2006.

Peña, M. A., Katsev, S., Oguz, T., and Gilbert, D.: Modeling dissolved oxygen dynamics and hypoxia, Biogeosciences, 7, 933957, doi:10.5194/bg-7-933-2010, 2010.

Penven, P., Roy, C., Brundrit, G. B., de Verdiere, A. C., Freon, P., Johnson, A. S., Lutjeharms, J. R. E., and Shillington, F. A.: A regional hydrodynamic model of upwelling in the Southern Benguela, S. Afr. J. Sci., 97, 472-475, 2001. 
Penven, P., Debreu, L., Marchesiello, P., and McWilliams, J. C.: Evaluation and application of the ROMS 1-way embedding procedure to the central California upwelling system, Ocean Model., 12, 157-187, doi:10.1016/j.ocemod.2005.05.002, 2006a.

Penven, P., Lutjeharms, J. R. E., and Florenchie, P.: Madagascar: A pacemaker for the Agulhas Current system?, Geophys. Res. Lett., 33, L17609, doi:10.1029/2006GL026854, 2006b.

Postel, L., Arndt, E. A., and Brenning, U.: Rostock zooplankton studies off West Africa, Helgoländer Meeresunters., 49, 829_ 847, 1995.

Ramaswamy, V., Boucher, O., Haigh, J., Hauglustaine, D., Haywood, J., Myhre, G., Nakajima, T., Shi, G., Solomon, S., Betts, R. E., Charlson, R., Chuang, C., Daniel, J. S., Del Genio, A., van Dorland, R., Feichter, J., Fuglestvedt, J., Forster, P.M., Ghan, S. J., Jones, A., Kiehl, J. T., Koch, D., Land, C., Lean, J., Lohmann, U., Minschwaner, K., Penner, J. E., Roberts, D. L., Rodhe, H., Roelofs, G. J., Rotstayn, L. D., Schneider, T. L., Schumann, U., Schwartz, S. E., Schwarzkopf, M. D., Shine, K. P., Smith, S., Stevenson, D. S., Stordal, F., Tegen, I., and Zhang, Y.: Radiative Forcing of Climate Change, in Climate Change 2001, Working Group I: The Scientific Basis, IPCC Third Assessment Report, Cambridge University Press, New York, United States (US), Pacific Northwest National Laboratory (PNNL), Richland, WA (US), 2001.

Redfield, J., Ketchum, B. H. and Richards, F. A.: The influence of organisms on the composition of sea-water, in: The sea, Vol 2, edited by: Hill, M. N., Academic Press, NY, 26-77, 1963.

Richardson, P. L., Lutjeharms, J. R. E., and Boebel, O.: Introduction to the "Inter-ocean exchange around southern Africa", DeepSea Res. Pt. II, 50, 1-12, doi:10.1016/S0967-0645(02)00376-4, 2003.

Robinson, C., Poulton, A. J., Holligan, P. M., Baker, A. R., Forster, G., Gist, N., Jickells, T. D., Malin, G., Upstill-Goddard, R., Williams, R. G., Woodward, E. M. S., and Zubkov, M. V.: The Atlantic Meridional Transect (AMT) Programme: A contextual view 1995-2005, Deep-Sea Res. Pt. II, 53, 1485-1515, doi:10.1016/j.dsr2.2006.05.015, 2006.

Rossi, V., López, C., Sudre, J., Hernández-García, E., and Garçon, V.: Comparative study of mixing and biological activity of the Benguela and Canary upwelling systems, Geophys. Res. Lett., 35, L11602, doi:10.1029/2008GL033610, 2008.

Rossi, V., López, C., Hernández-García, E., Sudre, J., Garçon, V., and Morel, Y.: Surface mixing and biological activity in the four Eastern Boundary Upwelling Systems, Nonlinear Proc. Geoph., 16, 557-568, 2009.

Schmid, C., Boebel, O., Zenk, W., Lutjeharms, J. R. E., Garzoli, S. L., Richardson, P. L., and Barron, C.: Early evolution of an Agulhas Ring, Deep-Sea Res. Pt. II, 50, 141-166, doi:10.1016/S09670645(02)00382-X, 2003.
Shchepetkin, A. F. and McWilliams, J. C.: A method for computing horizontal pressure-gradient force in an oceanic model with a nonaligned vertical coordinate, J. Geophys. Res., 108, 3090, doi:10.1029/2001JC001047, 2003.

Shchepetkin, A. F. and McWilliams, J. C.: The regional oceanic modeling system (ROMS): a split-explicit, free-surface, topography-following-coordinate oceanic model, Ocean Model., 9, 347-404, doi:10.1016/j.ocemod.2004.08.002, 2005.

Stramma, L., Johnson, G. C., Sprintall, J., and Mohrholz, V.: Expanding oxygen-minimum zones in the tropical oceans, Science, 320, 655-658, doi:10.1126/science.1153847, 2008.

Stramma, L., Johnson, G. C., Firing, E., and Schmidtko, S.: Eastern Pacific oxygen minimum zones: Supply paths and multidecadal changes, J. Geophys. Res., 115, C09011, doi:10.1029/2009JC005976, 2010.

Suntharalingam, P., Sarmiento, J. L., and Toggweiler, J. R.: Global significance of nitrous-oxide production and transport from oceanic low-oxygen zones: A modeling study, Glob. Biogeochem. Cy., 14, 1353-1370, 2000.

Suntharalingam, P., Buitenhuis, E., Le Quere, C., Dentener, F., Nevison, C., and Butler, J.: Quantifying the Impact of Anthropogenic Nitrogen Deposition on Oceanic Nitrous Oxide, Geophys. Res. Lett., 39, L07605, doi:10.1029/2011GL050778, 2012.

Taylor, K. E.: Summarizing multiple aspects of model performance in a single diagram, J. Geophys. Res., 106, 7183-7192, 2001.

Tilstone, G., Smyth, T., Poulton, A., and Hutson, R.: Measured and remotely sensed estimates of primary production in the Atlantic Ocean from 1998 to 2005, Deep-Sea Res. Pt. II, 56, 918-930, doi:10.1016/j.dsr2.2008.10.034, 2009.

Veitch, J., Penven, P., and Shillington, F.: The Benguela: A laboratory for comparative modeling studies, Prog. Oceanogr., 83, 296-302, doi:10.1016/j.pocean.2009.07.008, 2009.

Verheye, H. M. and Ekau, W.: Geochemistry and Ecology of the Namibian Upwelling System (GENUS Project) and St Helena Bay Monitoring Line (SHBML), cruise report, FRS Africana, 117 December 2009, 2009.

Wanninkhof, R.: Relationship Between Wind Speed and Gas Exchange Over the Ocean, J. Geophys. Res., 97, 7373-7382, 1992.

Ware, D. M.: Production characteristics of upwelling systems and the trophodynamic roleof hake, in: Benguela trophic functioning, 501-513, edited by: Payne, A. I. L., Brink, K. H., Mann, K. H., and Hilborn, R., 1992.

Yakushev, E. V., Pollehne, F., Jost, G., Kuznetso, I., Schneider, B., and Urnlauf, L.: Analysis of the water column oxic/anoxic interface in the Black and Baltic seas with a numerical model, Mar. Chem., 107, 388-410, doi:10.1016/j.marchem.2007.06.003, 2007.

Yool, A., Martin, A. P., Fernandez, C., and Clark, D. R.: The significance of nitrification for oceanic new production, Nature, 447, 999-1002, doi:10.1038/nature05885, 2007. 